\title{
Two distinct GUCY2C circuits with PMV (hypothalamic) and SN/VTA (midbrain) origin
}

\author{
D. J. Merlino' · J. R. Barton ${ }^{1}$ - B. A. Charsar ${ }^{2}$ - M. D. Byrne ${ }^{2}$. J. A. Rappaport ${ }^{1} \cdot$ R. J. Smeyne S A. C. Lepore $^{2}$. \\ A. E. Snook ${ }^{1}$. S. A. Waldman ${ }^{1}$
}

Received: 15 June 2018 / Accepted: 24 August 2019 / Published online: 4 September 2019

○) Springer-Verlag GmbH Germany, part of Springer Nature 2019

\begin{abstract}
Guanylyl cyclase $\mathrm{C}$ (GUCY2C) is the afferent central receptor in the gut-brain endocrine axis regulated by the anorexigenic intestinal hormone uroguanylin. GUCY2C mRNA and protein are produced in the hypothalamus, a major center regulating appetite and metabolic homeostasis. Further, GUCY2C mRNA and protein are expressed in the ventral midbrain, a principal structure regulating hedonic reward from behaviors including eating. While GUCY2C is expressed in hypothalamus and midbrain, its precise neuroanatomical organization and relationship with circuits regulating satiety remain unknown. Here, we reveal that hypothalamic GUCY2C mRNA is confined to the ventral premammillary nucleus (PMV), while in midbrain it is produced by neurons in the ventral tegmental area (VTA) and substantia nigra (SN). GUCY2C in the PMV is produced by $46 \%$ of neurons expressing anorexigenic leptin receptors, while in the VTA/SN it is produced in most tyrosine hydroxylaseimmunoreactive neurons. In contrast to mRNA, GUCY2C protein is widely distributed throughout the brain in canonical sites of PMV and VTA/SN axonal projections. Selective stereotaxic ablation of PMV or VTA/SN neurons eliminated GUCY2C only in their respective canonical projection sites. Conversely, specific anterograde tracer analyses of PMV or VTA/SN neurons confirmed distinct GUCY2C-immunoreactive axons projecting to those canonical locations. Together, these findings reveal two discrete neuronal circuits expressing GUCY2C originating in the PMV in the hypothalamus and in the VTA/SN in midbrain, which separately project to other sites throughout the brain. They suggest a structural basis for a role for the GUCY2C-uroguanylin gut-brain endocrine axis in regulating homeostatic and behavioral components contributing to satiety.
\end{abstract}

Keywords Guanylyl cyclase C $\cdot$ Ventral premammillary nucleus $\cdot$ Ventral tegmental area $\cdot$ Substantia nigra $\cdot$ Leptin receptor · Obesity

\section{Abbreviations}

Acb Nucleus accumbens

BST Bed nucleus of the stria terminalis

CeL Lateral part of the central amygdalar nucleus

Electronic supplementary material The online version of this article (https://doi.org/10.1007/s00429-019-01949-y) contains supplementary material, which is available to authorized users.

D. J. Merlino and J. R. Barton contributed equally to manuscript.

S. A. Waldman

scott.waldman@jefferson.edu

1 Department of Pharmacology and Experimental Therapeutics, Thomas Jefferson University, 1020 Locust Street, 368 JAH, Philadelphia, PA 19107, USA

2 Department of Neuroscience, Vickie and Jack Farber Institute for Neuroscience, Sidney Kimmel Medical College at Thomas Jefferson University, Philadelphia, PA, USA

$\begin{array}{ll}\mathrm{CPu} & \text { Caudoputamen } \\ \text { CTCF } & \text { Corrected total cell fluorescence } \\ \text { cGMP } & \text { Cyclic GMP } \\ \text { ER } & \text { Endoplasmic reticulum } \\ \text { GUCA2B } & \text { Uroguanylin } \\ \text { GUCY2C } & \text { Guanylyl cyclase C } \\ \text { HFD } & \text { High-fat diet } \\ \text { ISH } & \text { In situ hybridization } \\ \text { KO } & \text { Knock out } \\ \text { LepR } & \text { Leptin receptor } \\ \text { LHA } & \text { Lateral hypothalamic area } \\ \text { LSV } & \text { Ventral part of the lateral septal nucleus } \\ \text { MPO } & \text { Medial preoptic nucleus } \\ \text { NMDA } & N \text {-methyl-D-aspartate } \\ \text { OTu } & \text { Olfactory tubercle } \\ \text { PA } & \text { Posterior amygdalar nucleus } \\ \text { PMV } & \text { Ventral premammillary nucleus } \\ \text { POMC } & \text { Pro-opiomelanocortin }\end{array}$




$\begin{array}{ll}\text { qRT-PCR } & \begin{array}{l}\text { Quantitative reverse transcriptase polymerase } \\ \text { chain reaction }\end{array} \\ \text { SNc } & \text { Substantia nigra pars compacta } \\ \text { ST } & \text { Bacterial heat-stable enterotoxin } \\ \text { TH } & \text { Tyrosine hydroxylase } \\ \text { TU } & \text { Tuberal nucleus } \\ \text { VMHvl } & \text { Ventrolateral aspect of the ventromedial } \\ & \text { nucleus } \\ \text { VTA } & \text { Ventral tegmental area }\end{array}$

\section{Introduction}

Obesity is a global pandemic affecting 2.1 billion people worldwide, with economic costs expected to exceed $\$ 125$ billion in the United States by 2030 (Wang et al. 2011; Ng et al. 2014; Kopelman 2007). Mechanisms underlying the onset of obesity remain poorly understood, and as such, treatment options remain limited. Fundamentally, dysregulation of the signals balancing appetite and energy expenditure lead to excess caloric intake, ultimately resulting in obesity and associated comorbidities (Berkseth et al. 2014; Zigman et al. 2016; Williams et al. 2014; Li et al. 2012). There is an unmet need to define pathways modulating appetite and satiety, to reveal mechanisms underlying dysregulation of energy balance, and to identify potential new therapeutic targets to treat obesity.

Peripheral organs relay information about caloric intake and energy reserves to the brain, in part, through endocrine hormone signaling. Satiety hormones from the gut, pancreas, and adipose circulate to the brain to regulate food consumption, acting predominantly on receptors expressed in the hypothalamus. The hypothalamus encompasses discrete nuclei with specific, well-characterized functions that serve as the primary site of integration between anorexigenic (inhibiting food intake) and orexigenic (stimulating food intake) signaling (Waterson and Horvath 2015). One putative anorexigenic (appetite suppressing) hormone receptor expressed in the hypothalamus is guanylyl cyclase $\mathrm{C}$ (GUCY2C), a transmembrane receptor for the intestinal hormone uroguanylin (GUCA2B) (Folgueira et al. 2016a; Kim et al. 2016; Valentino et al. 2011). Binding of uroguanylin to the GUCY2C extracellular ligand-binding domain activates the intracellular catalytic domain, resulting in the intracellular accumulation of the second messenger cyclic GMP (cGMP). Mice deficient in GUCY2C (Gucy $\left.2 c^{-/-}\right)$display increased food intake, accelerated weight gain, and increased incidence of obesity comorbidities, including hypertriglyceridemia with hepatic steatosis, cardiac hypertrophy, hyperinsulinemia, and impaired glycemic control (Valentino et al. 2011; Kim et al. 2016). Like other anorexigenic endocrine signaling axes, chronic exposure to high-fat diet (HFD) impairs the GUCA2B-GUCY2C gut-brain signaling axis (Di Guglielmo et al. 2017; Di Guglielmo et al. 2018; Folgueira et al. 2016b; Rodriguez et al. 2016; Clemmensen et al. 2017). However, unlike the anorexigenic axes regulated by leptin and insulin, which exhibit receptor desensitization in the context of obesity, HFD-mediated dysregulation of the GUCA2B-GUCY2C axis involves elimination of intestinal hormone expression through ER stress (Kim et al. 2016). In fact, chronic HFD increases hypothalamic GUCY2C expression (Kim et al. 2016).

Thus, the GUCY2C endocrine axis could serve as a therapeutic target to regulate appetite and treat obesity. In that context, conditional transgenic expression of uroguanylin in brain, which cannot be suppressed by HFD, reduces feeding and opposed weight gain in mice on a HFD (Kim et al. 2016). While these observations support a role for brain GUCY2C in regulating appetite and satiety, its precise distribution and associated neural pathways remain incompletely defined. Previous studies demonstrated that GUCY2C mRNA and protein is expressed in hypothalamus and midbrain (Begg et al. 2014; Folgueira et al. 2016a; Gong et al. 2011; Valentino et al. 2011). Here, we reveal that GUCY2Cexpressing neurons comprise two distinct brain circuits. In the first, tyrosine hydroxylase $(\mathrm{TH})(-)$, GUCY2C(+) neurons from the ventral premammillary nucleus (PMV) project to hypothalamic nuclei [medial preoptic nucleus (MPO), arcuate nucleus (ARC), ventrolateral aspect of the ventromedial hypothalamic nucleus (VMHvl)], as well as the ventral part of the lateral septal nucleus (LSV), the bed nucleus of the stria terminalis (BST), and the posterior amygdalar nucleus (PA). In the second, $\mathrm{TH}(+), \mathrm{GUCY} 2 \mathrm{C}(+)$ neurons from the substantia nigra pars compacta $(\mathrm{SNc})$ and the ventral tegmental area (VTA) project to the lateral hypothalamic area (LHA), lateral part of the central amygdalar nucleus (CeL), olfactory tubercle (OTu), nucleus accumbens (Acb), and caudoputamen $(\mathrm{CPu})$. These observations are consistent with a role for GUCY2C in homeostatic circuits driven by energy balance in the hypothalamus, and hedonic reward circuits regulated by dopaminergic neurons of the midbrain. Moreover, the distribution of GUCY2C protein throughout the brain suggests roles for GUCY2C beyond appetite regulation.

\section{Materials and methods}

\section{Mice}

Animal studies were performed in accordance with IACUC protocols and procedures; male or female C57BL/6 mice ages 8-15 weeks were used for all experiments. GUCY2C $\mathrm{KO}$ and LepR-cre-LacZ mice were described previously (Kim et al. 2016; Schulz et al. 1997; Scott et al. 2009; Valentino et al. 2011). 


\section{Human tissue samples}

Control human brain samples were acquired from the NIH NeuroBioBank (neurobiobank.nih.gov) for mRNA and immunofluorescence analysis. Details regarding sample source are provided in Suppl. Table 1.

\section{Immunofluorescence}

Following perfusion of mice with ice-cold PBS followed by $4 \%$ paraformaldehyde, brains were extracted and incubated in $4 \%$ PFA at $4{ }^{\circ} \mathrm{C}$ for $24-48 \mathrm{~h}$, and then cryoprotected by incubation in $30 \%$ sucrose in PBS at $4{ }^{\circ} \mathrm{C}$ until brains sank (24-72 h). Brains were frozen in OCT medium by submerging in dry ice-cooled methanol and stored at $-80^{\circ} \mathrm{C}$ until sectioning. Fifty-micron sections were cut using a cryostat, and then stored floating in cryoprotectant until staining. Each "wash" step below represents four consecutive 10-min incubations in PBS with 0.1\% tween-20 (PBST). Epitope retrieval was performed on floating sections by incubating in $\mathrm{pH} 9$ retrieval solution (Agilent, Santa Clara, CA, USA) for $20 \mathrm{~min}$ at $80^{\circ} \mathrm{C}$. Samples were blocked for $1 \mathrm{~h}$ in blocking buffer $[10 \%$ milk (w/v) in PBS with $0.3 \%$ Triton-X] and then incubated, shaking in $1^{\circ}$ antibody solution (diluted in blocking buffer) overnight at $4{ }^{\circ} \mathrm{C}$. After a wash step, samples were incubated, shaking in blocking buffer with $2^{\circ}$ antibody and nuclear counterstain DAPI for $90 \mathrm{~m}$ at room temperature. For all stains except GUCY2C, a fluorophoreconjugated $2^{\circ}$ antibody was used. To stain GUCY2C, a peroxidase-conjugated $2^{\circ}$ antibody was used, followed by tyramine-amplification: samples were washed and then incubated in tyramide-FITC, at a final concentration of $100 \mu \mathrm{g} / \mathrm{mL}$ in PBS with $0.003 \% \mathrm{H}_{2} \mathrm{O}_{2}$ for $10 \mathrm{~min}$ (Hopman et al. 1998). Following a final series of washes, samples were mounted onto slides with Prolong Diamond antifade mounting media (Thermo Fisher, Waltham, MA). LepR(+) neurons were identified by immunofluorescence by detection of $\beta$-galactosidase in LepR-Cre(+), ROSA-STOP ${ }^{\mathrm{fl}}$-LacZ $(+)$ mice (Scott et al. 2009). Antibody IDs and concentrations are listed in Suppl. Table 2. Three mice $(n=3)$ were either co-labelled for GUCY2C and LacZ (LepR), or co-labelled for GUCY2C and TH to perform cell counting. Confocal images were taken of 2 different $50 \mu \mathrm{m}$ sections from each mouse for each region. Cells were quantified from 2 different optical sections (at least $6 \mu \mathrm{m}$ apart) for each $50 \mu \mathrm{M}$ section.

\section{Stereotaxic ablations}

PMV and VTA ablation studies were performed with NMDA, as described previously (Donato et al. 2013; Donato et al. 2009; Donato et al. 2011). Briefly, mice were injected with $100 \mathrm{~nL}$ of 0.15 M NMDA (Sigma, St. Louis, MO, USA), diluted in PBS and the anterograde tracer
Fluoro-Ruby (Sigma). Coordinates for injections were obtained from the Allen Mouse Brain Connectivity Atlas, (Technical white paper: Injection sites and steroetaxic coordinates for antegrade projecome (brain-wide) 2016), PMV: AP - 2.3, ML \pm 0.6 , DV 5.7; VTA: AP - 3.16, $\mathrm{ML} \pm 0.63$, DV 4.54. After 10 days, mice were sacrificed and brains processed for immunofluorescence. Six mice displayed NeuN ablation patterns of sufficient specificity and were included in GUCY2C projection analyses (3 PMV and $3 \mathrm{SNc} / \mathrm{VTA}$ ). For each mouse, every third section was stained, and every stained section containing a region of interest was included in the calculation of GUCY2C protein expression. GUCY2C protein expression was calculated as CTCF (described in the statistical analysis section); final values represent the average CTCF compared to control for each ROI.

\section{Stereotaxic viral injections}

Anterograde tracing was performed with Adeno-associated virus serotype-2 (AAV2) vector that drives expression of mCherry anterograde axonal tracer (George M. Smith, Temple University) (Urban et al. 2018). Mice were injected unilaterally with $100 \mathrm{~nL}$ of AAV2-mCherry at a rate of 0.4 $\mu \mathrm{L} / \mathrm{min}$, leaving the needle at the injection site for $10 \mathrm{~min}$ post-injection before retracting from the skull. Coordinates for AAV2 injections were PMV: AP $-2.25, \mathrm{ML} \pm 0.50$, DV 5.70; VTA: AP - 3.16, ML \pm 0.63 , DV 4.54. After 14 days mice were sacrificed and brains processed for immunofluorescence. mCherry protein expression was detected using Living Colors ${ }^{\circledR}$ DsRed antibody (Clontech, Mountain View, CA, USA). Four mice (two PMV and two SNc/VTA) displayed injection patterns specific for PMV and VTA/SNc; all mice with off-target injections were excluded from the analysis. mCherry protein expression was calculated as CTCF (described in the statistical analysis section) and ROIs were determined in the GUCY2C channel to determine mCherry expression in GUCY2C + and GUCY2C- regions. Final values represent the average $\mathrm{CTCF}$ compared to injected for each ROI.

\section{Quantitative RT-PCR}

Hypothalamic nuclei were microdissected (Suppl Fig. 1) and RNA purified and analyzed as described (Kim et al. 2016). Primer/probe sets from TaqMan Gene Expression Assays (Thermo Fisher) were used to quantify mRNA expression of mouse Gucy2c (Mm01267705_m1), mouse Actb (Mm01205647_g1), human GAPDH (Hs02758991_g1), and human GUCY2C (Hs00192035_m1). Five mice were dissected for each region. 


\section{Statistical analyses}

All data were analyzed using GraphPad Prism v7. GUCY2C quantification in defined regions of interest (ROIs) for Figs. 5 and 6 was performed by calculating corrected total cell fluorescence (CTCF) (Kim et al. 2014), using the following equation:

\section{$\mathrm{CTCF}=\mathrm{ROI}$ Integrated density \\ $-($ ROI Area $\times$ Mean Background Fluorescence $)$}

$\mathrm{CTCF}$ for each tissue section was calculated relative to control ROI; data are expressed as mean \pm SEM. NeuN quantification in Fig. 5 was performed using the analyze particles plugin in FIJI (NIH), using the Otsu automatic threshold method to generate binary masks for particle identification. Two-way ANOVA was used to calculate significance between control and NMDA-treated sides; $p<0.05$ was considered statistically significant. Error bars depict SEM unless otherwise specified.

\section{Results}

\section{Gucy2c expression is limited to discrete nuclei in hypothalamus and midbrain}

Previous analyses suggested that GUCY2C protein was broadly expressed in nuclei in hypothalamus and midbrain (Kim et al. 2016; Gong et al. 2011). In contrast, in situ hybridization (ISH; Allen Institute for Brain Science; experiments 69734851 and 73992911) (Lein et al. 2007) suggested that GUCY2C mRNA expression exhibited a more restricted pattern of expression in those regions, concentrated in the VTA and SNc of the midbrain and the PMV in hypothalamus (Fig. 1a-c). Quantitative RT-PCR of microdissected nuclei confirmed ISH analyses, demonstrating mRNA expression primarily in PMV and VTA/SNc, but not in other regions that had previously demonstrated GUCY2C protein (Fig. 1d). Supporting this, transcriptomic analyses of microdissected nuclei revealed GUCY2C mRNA in the VTA and SNc, but not other regions in the brain (this study

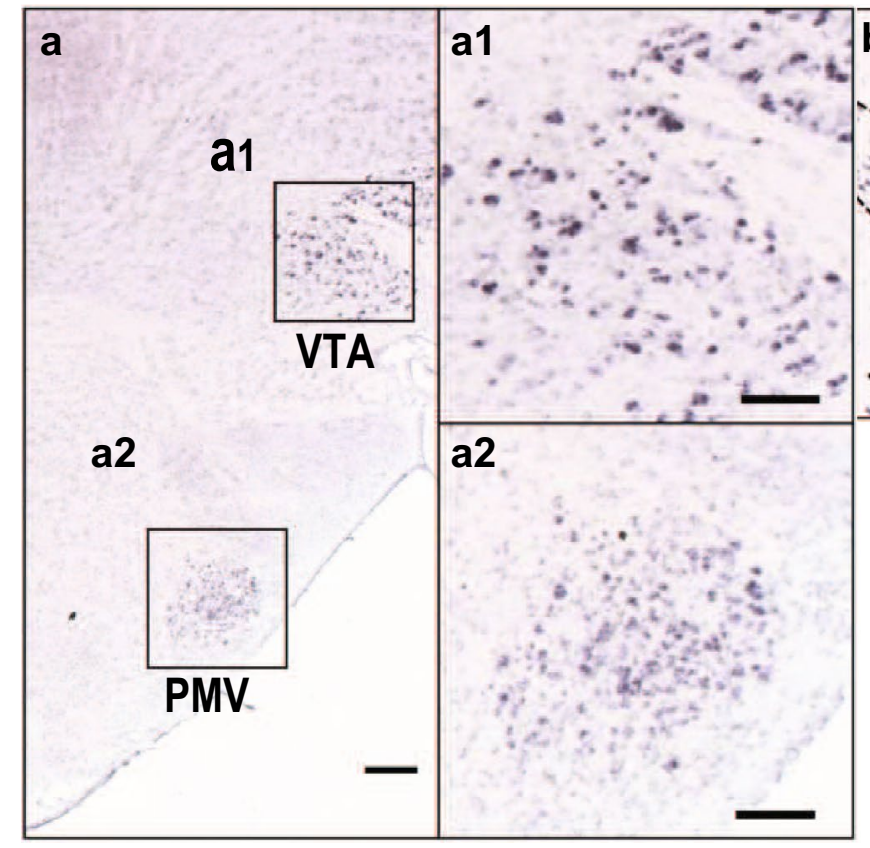

Fig. 1 CNS GUCY2C mRNA expression is restricted to the hypothalamic ventral premammillary nucleus and neurons in the VTA/ SNc. (a sagittal; b, c coronal). In situ hybridization (Allen Institute for Brain Science; experiments 73992911 and 69734851) (Lein et al. 2007) revealed robust GUCY2C mRNA expression in the PMV and the VTA/SNc, while mRNA was absent in the ARC. d Quantitative RT-PCR of microdissected hypothalamic nuclei or tissue controls demonstrated that hypothalamic GUCY2C mRNA is restricted to the premammillary nucleus. For each region, $n=5$ mice per group, with mRNA analyzed in duplicate; data represent mean \pm SD. VTA/ $S N C$ ventral tegmental area/substantia nigra, pars compacta, $P M V$

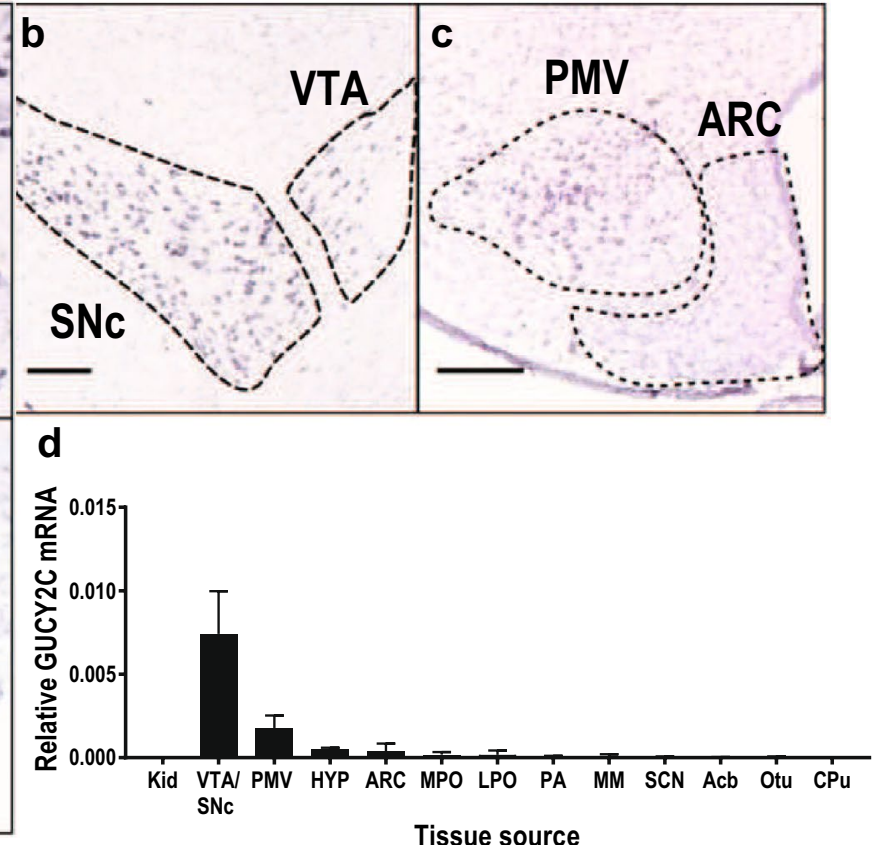

ventral premammillary nucleus, hyp bulk hypothalamus, $A R C$ arcuate nucleus, $M P O$ medial preoptic nucleus, $L P O$ lateral preoptic nucleus, $P A$ posterior amygdalar nucleus, $M M$ medial mamillary nucleus, $S C N$ suprachiasmatic nucleus, $A c b$ nucleus accumbens, $O T u$ olfactory tubercle, $С p u$ caudoputamen. Scale bars $=200 \mu \mathrm{m}$ in $\mathbf{a}-\mathbf{c}$; $100 \mu \mathrm{m}$ in a1 and a2 Source images for $\mathbf{a}-\mathbf{c}$ can be found at the following links: a http://mouse.brain-map.org/experiment/siv?id=69734 851\&imageId=69609220. b http://mouse.brain-map.org/experiment /siv?id=73992911\&imageId=73952737. c http://mouse.brain-map. org/experiment/siv?id=73992911\&imageId $=73952743$ 
did not microdissect the PMV) (Suppl. Figure 2) (Kasukawa et al. 2011).

\section{GUCY2C is expressed by distinct neurons in hypothalamus and midbrain}

A sensitive and specific monoclonal antibody to GUCY2C (Suppl. Figure 2) revealed subpopulations of GUCY2C(+) cells in the PMV and VTA/SNc in wild type (Gucy $\left.2 \mathrm{c}^{+/+}\right)$,

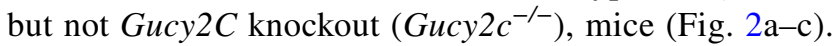
GUCY2C expression in the VTA/SNc was found in, but not limited to, dopaminergic, tyrosine hydroxylase-expressing $[\mathrm{TH}(+)]$ neurons [NeuN(+)] (Fig. 2b, c) (Gong et al. 2011), correlating closely with GUCY2C promoter activity in those neurons quantified by ChIP-Seq [BioProject Accession: PRJNA420978, ID: 420978 Series GSE107309 (ncbi. nlm.nih.gov/bioproject/PRJNA420978); Suppl. Figure 3]. In contrast, GUCY2C in PMV is produced by $\mathrm{TH}(-)$ neurons, particularly in neurons expressing the anorexigenic leptin receptor (LepR), which is enriched in the PMV (Patterson et al. 2011) (Fig. 2b). LepR(+) neurons were detected by immunofluorescence of $\beta$-galactosidase in LepR-Cre $(+)$ mice expressing a cre-inducible LacZ transgene (Scott et al. 2009). GUCY2C in the PMV co-localized with the neuronal marker NeuN, but not with the glial marker GFAP (Suppl. Figure $4 \mathrm{a}, \mathrm{b})$. GUCY2C protein was localized in cell bodies and projections in hypothalamic LepR(+) and midbrain $\mathrm{TH}(+)$ neurons in mouse (Fig. 2b, c) and human (Fig. 2d, e), aligning with human GUCY2C mRNA expression (Fig. 2f). In the midbrain, $88 \%$ of $\mathrm{TH}(+)$ neurons in the $\mathrm{SNc}$, while $65 \%$ of $\mathrm{TH}(+)$ neurons in the VTA, expressed GUCY2C by immunofluorescence (Fig. $2 \mathrm{~g}$, h). Conversely, $91 \%$ of GUCY2C(+) neurons in the SNc and $86 \%$ of GUCY2C(+) neurons in the VTA were immunoreactive for TH (Fig. $2 \mathrm{~g}$, h). In the hypothalamus, $46 \%$ of $\operatorname{LepR}(+)$ neurons also were GUCY2C(+), while $64 \%$ of GUCY2C(+) neurons were LepR(+) (Fig. 2i). Co-expression of GUCY2C and LepR provide the first structural basis for modulation of appetite by the GUCY2C endocrine axis (Kim et al. 2016; Valentino et al. 2011).

\section{GUCY2C protein distributes in brain through axonal projections from PMV or VTA/SNc}

Broad immunofluorescence of GUCY2C in brain with limited mRNA expression confined to discrete nuclei, along with GUCY2C protein in axons, suggest that GUCY2C is produced in PMV and VTA/SNc neurons and distributed to other areas along axonal projections. Anterograde tracing of PMV LepR(+) neurons, [mouse brain connectivity atlas studies 167656152 and 179904203 (Oh et al. 2014)]; identified the posterior amygdalar nucleus (PA), ventral part of the lateral septal nucleus (LSV), bed nucleus of the stria terminalis (BST), medial preoptic nucleus (MPO), arcuate nucleus (ARC) and tuberal nucleus (TU), which overlaps with the ventrolateral aspect of the ventromedial nucleus (VMHvl), as nuclei with a high density of PMV projections (Fig. 3a), in close agreement with previous PMV tracing studies (Canteras et al. 1992). These nuclei demonstrated robust GUCY2C protein expression (Fig. 3b), in the absence of GUCY2C mRNA expression (Fig. 1a, Suppl. Figure 1). The absence of immunofluorescence staining of $G u c y 2 c^{-1-}$ mice confirmed the specificity of the signal (Suppl. Figure 5). GUCY2C immunofluorescence in these nuclei did not co-localize with $\mathrm{TH}$ or NeuN, suggesting that they were not derived from the VTA/SNc or local neurons, respectively (Fig. 3c). Similarly, regions receiving projections from the VTA/SNc, such as the caudoputamen $(\mathrm{CPu})$, olfactory tubercle (OTu), lateral part of the central amygdalar nucleus ( $\mathrm{CeL})$, nucleus accumbens (Acb), and lateral hypothalamic area (LHA) (Beier et al. 2015) expressed GUCY2C protein, but not mRNA, in $\mathrm{TH}(+)$ axons, but not cell bodies (Fig. 4a, b). Together, these observations suggest that two distinct GUCY2C circuits exist originating from the $\mathrm{PMV}$ in the hypothalamus, which is devoid of $\mathrm{TH}$, and from the VTA/SNc in the midbrain in neurons co-staining with TH. In both circuits, GUCY2C appears to be transcribed (mRNA) and translated (protein) in neuronal cell bodies, and then distributed along the length of axons, which project to other nuclei (no mRNA; only protein).

\section{GUCY2C characterizes two discrete circuits emerging from the hypothalamus and midbrain}

GUCY2C is expressed by immunofluorescence in axons in hypothalamic nuclei that canonically receive PMV projections. The absence of $\mathrm{TH}$ in those axons suggests that they arise from the PMV as an independent circuit, rather than from the VTA/SNc. To confirm this, and to rule out the possibility that the projections arise from another undiscovered population of GUCY2C(+) neurons, the PMV was unilaterally ablated by stereotaxic injection of the excitotoxic agent NMDA, which selectively kills neurons at the injection site without affecting fibers of passage (Donato et al. 2013; Donato et al. 2011; Donato et al. 2009; Sisk et al. 1988). Loss of NeuN-expressing cells in the PMV but not the VTA/SNc or ARC confirmed the specificity of the injections (Fig. 5a-c). As expected, PMV ablation reduced local GUCY2C immunofluorescence without affecting GUCY2C in the VTA/SNc (Fig. 5a, b, d). PMV ablation eliminated ipsilateral GUCY2C immunofluorescence in all nuclei receiving projections from the PMV (Fig. 6a-e), but not from the VTA/SNc (Fig. 6 h; Suppl. Figures 6, 7).

Conversely, the VTA/SNc also was unilaterally ablated by NMDA injection. Loss of NeuN-expressing cells in the VTA/SNc, but not the PMV confirmed the anatomical 

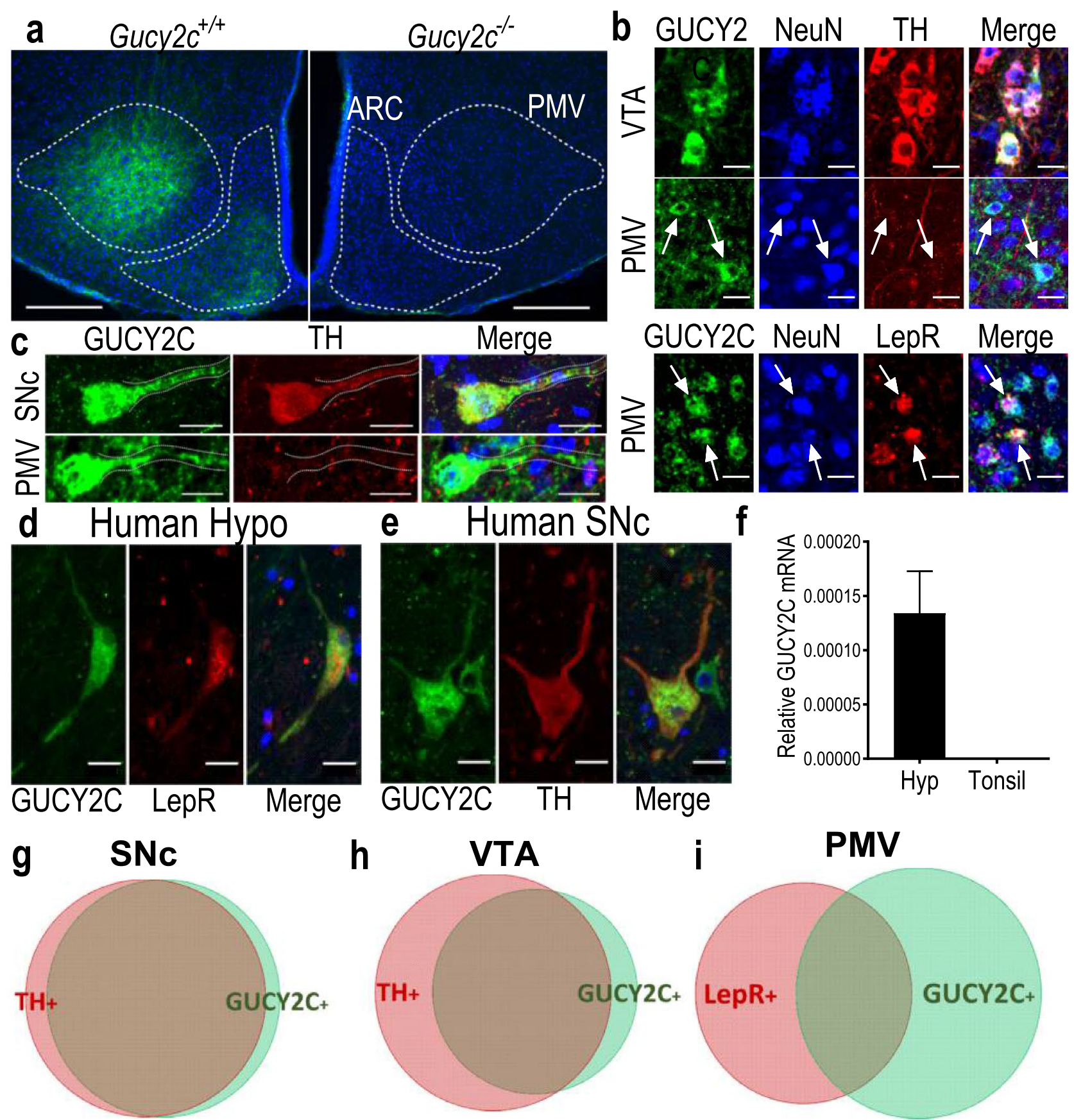

h
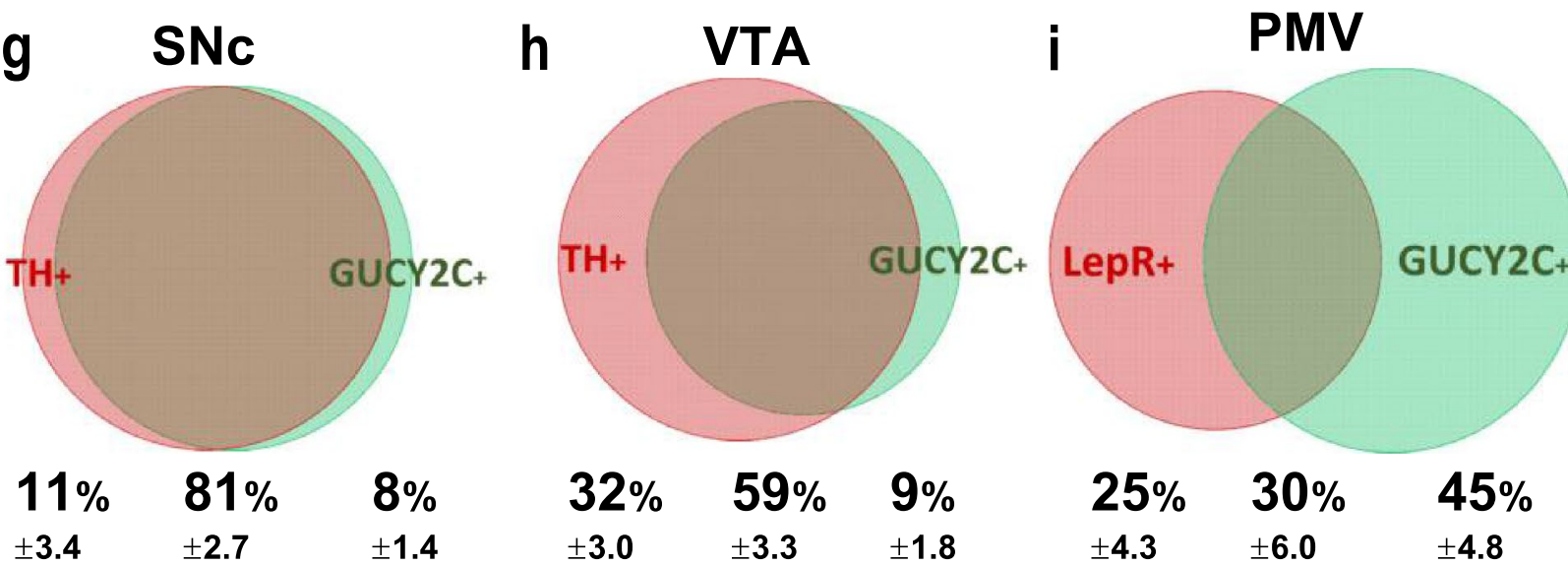

$\pm 4.3 \quad \pm 6.0 \quad \pm 4.8$

specificity of injections (Fig. 5e-g). NMDA ablation reduced GUCY2C immunofluorescence in the VTA/SNc but not in the PMV or ARC (Fig. 5 h). Further, NMDA ablation substantially reduced ipsilateral GUCY2C immunofluorescence in all nuclei receiving projections from the VTA/SNc (Fig. 6f, g), but not from the PMV (Fig. 6i; Suppl. Figure 7b-f). The absence of GUCY2C immunofluorescence in ipsilateral projection sites of the VTA/SNc mice suggests that neurons comprising the interhemispheric nigrostriatal pathway (approximately 1-3\% of VTA/SNc neurons) may not express GUCY2C (Lieu and Subramanian 2012).

GUCY2C immunofluorescence in nuclei receiving projections from the hypothalamus and midbrain was confirmed by anterograde tracing of GUCY2C neurons from PMV and VTA/SNc. Injection of AAV2-mCherry (Urban et al. 2018) into the PMV (Fig. 7) or VTA (Fig. 8) revealed co-expression of mCherry and GUCY2C protein in neurons and axons in the hypothalamus and midbrain, respectively. Further, 
4Fig. 2 Hypothalamic neurons in the PMV express GUCY2C protein in somas and projections. a Immunofluorescence of mouse hypothalamus revealed a subpopulation of GUCY2C (green)-expressing cells emanating from the PMV, with expression in adjacent arcuate nucleus, in $G u c y 2 c^{+/+}$, but not $G u c y 2 c^{-/-}$, mice. Blue: DAPI. b GUCY2C $(+)$ cells in the VTA and PMV express the neuronal marker NeuN. While GUCY2C(+) neurons in the VTA express TH by immunofluorescence, GUCY2C(+) neurons in the PMV are $\mathrm{TH}(-)$, and may be LepR(+). Arrows indicate PMV NeuN(+), GUCY2C(+) cells that do not express TH (middle column), or express LepR (bottom column). c Neurons in the SNc (top) and PMV (bottom) express GUCY2C protein in cell bodies and neuronal processes (dotted line). GUCY2C expression in human hypothalamus and midbrain matches the pattern of expression in mice. (d) In humans, hypothalamic GUCY $2 \mathrm{C}^{+}$neurons are LepR(+) while e midbrain GUCY2C neurons are $\mathrm{TH}(+)$. $\mathbf{f}$ GUCY2C mRNA is expressed in human hypothalamus, but not tonsil (negative control); $n=4$ human hypothalamic samples (see Suppl. Table 1 for details); for tonsil samples, $n=3$. Neuronal enumeration revealed that in the: $\mathbf{g ~ S N c}, 88 \%$ of $\mathrm{TH}(+)$ neurons (red bubble) are $\mathrm{GUCY} 2 \mathrm{C}(+)$ (green bubble); (h) VTA, 65\% of $\mathrm{TH}(+)$ neurons are $\mathrm{GUCY} 2 \mathrm{C}(+)$; and (i) $\mathrm{PMV}, 46 \%$ of $\mathrm{LepR}(+)$ neurons (red bubble) are also GUCY2C(+) (green bubble). Bubble size and overlap are relative to the combined total of GUCY2C(+) and $\mathrm{TH}(+)$ or LepR(+) neurons in the VTA/SNc or PMV, respectively. Scale bars: a $200 \mu \mathrm{m}$; b-f $20 \mu \mathrm{m}$; F inset: $5 \mu \mathrm{m}$

anterograde tracing of axons from the PMV revealed coexpression of mCherry and GUCY2C protein in projection sites emanating from the hypothalamus, but not the midbrain (Fig. 7). Conversely, anterograde tracing of axons from the VTA/SNc revealed co-expression of mCherry and GUCY2C protein in projection sites emanating from the midbrain, but not the hypothalamus (Fig. 8). Together, NMDA ablation and mCherry anterograde tracing reveal two separate and distinct circuits of GUCY2C-immunofluorescent neurons that emanate from the PMV in the hypothalamus and the VTA/SNc in the midbrain.

\section{Discussion}

Here, we provide the first map of neuronal GUCY2C circuits in the central nervous system (Fig. 9). GUCY2C(+), LepR(+) neurons originate in the PMV in the hypothalamus and project to discrete distant nuclei in the hypothalamus, striatopallidum, and cortical subplate. Separately, GUCY2C(+), TH(+) dopaminergic neurons reside in the VTA/SNc in the midbrain and project to the LHA, OTu, and $\mathrm{CPu}$, and CeL. In the PMV and VTA/SNc, GUCY2C appears to be transcribed (mRNA) and translated (protein) in neuronal, rather than glial, cells and then transported along the length of axons (protein only, no mRNA), including to presynaptic terminals, projecting to distant nuclei. GUCY2C protein and mRNA expression in the human brain closely recapitulates that in mice, suggesting that GUCY2C neurobiology is likely conserved across species. Together, these observations suggest that GUCY2C regulates two independent circuits in the central nervous system, including a hypothalamic circuit centered in the PMV and a separate midbrain circuit centered in the VTA/SNc.

Until 2011, the canonical GUCY2C signaling axis was restricted to intestine (Gong et al. 2011; Kuhn 2016; Valentino et al. 2011). GUCY2C is expressed in apical brush border membranes of epithelial cells where it is stimulated by the paracrine hormones uroguanylin in small intestine and guanylin in the colorectum (Waldman and Camilleri 2018). In turn, GUCY2C stimulation regulates the cystic fibrosis transmembrane conductance regulator chloride channel and the sodium-hydrogen exchanger controlling intestinal fluid and electrolyte homeostasis (Waldman and Camilleri 2018). Excess stimulation of GUCY2C by bacterial heat-stable enterotoxins, which dysregulates intestinal fluid and electrolyte secretion, produces secretory diarrhea (Waldman and Camilleri 2018). Further, paracrine hormoneGUCY2C interactions regulate canonical cell processes that maintain the organization of the crypt-surface axis, including the balance between proliferation and differentiation, DNA damage sensing and repair, glycolytic and oxidative metabolism, and epithelial-mesenchymal cross-talk (Kuhn 2016; Waldman and Camilleri 2018). Indeed, suppression of hormone expression, which silences GUCY2C signaling, plays an essential role in the molecular pathogenesis of colorectal cancer ( $\mathrm{Li}$ et al. 2017; Li et al. 2007; Lin et al. 2010; Waldman and Camilleri 2018). In that context, selective expression on the luminal surface of normal intestinal epithelial cells, but persistent over-expression by metastatic colorectal cancer cells outside the intestine makes GUCY2C a particularly promising biomarker and therapeutic target for managing patients with GI malignancies (Frick et al. 2005; Magee et al. 2018; Marszalowicz et al. 2014; Weinberg et al. 2017).

Beyond these local paracrine signaling activities in intestine, there is an emerging paradigm in which a novel GUCY2C endocrine gut-brain axis regulates feeding, energy and metabolic homeostasis, and body weight. Ingestion of food induces endocrine secretion of prouroguanylin from the small intestine into the circulation in mice and humans (Di Guglielmo et al. 2018; Folgueira et al. 2018; Folgueira et al. 2016b; Kim et al. 2016; Rodriguez et al. 2016; Valentino et al. 2011). Circulating prouroguanylin, but not proguanylin, is processed by the hypothalamus to the mature uroguanylin hormone (Valentino et al. 2011). Uroguanylin binds to and activates GUCY2C in hypothalamus, inducing cGMP accumulation (Kim et al. 2016; Valentino et al. 2011). Hormone activation of central GUCY2C-cGMP signaling induces hypothalamic POMC and c-Fos expression associated with satiety, decreasing feeding (Folgueira et al. 2016a; Folgueira et al. 2016b; Kim et al. 2016; Valentino et al. 2011). Peripheral GUCY2C ligands like uroguanylin or the bacterial heat-stable enterotoxin induce these central 


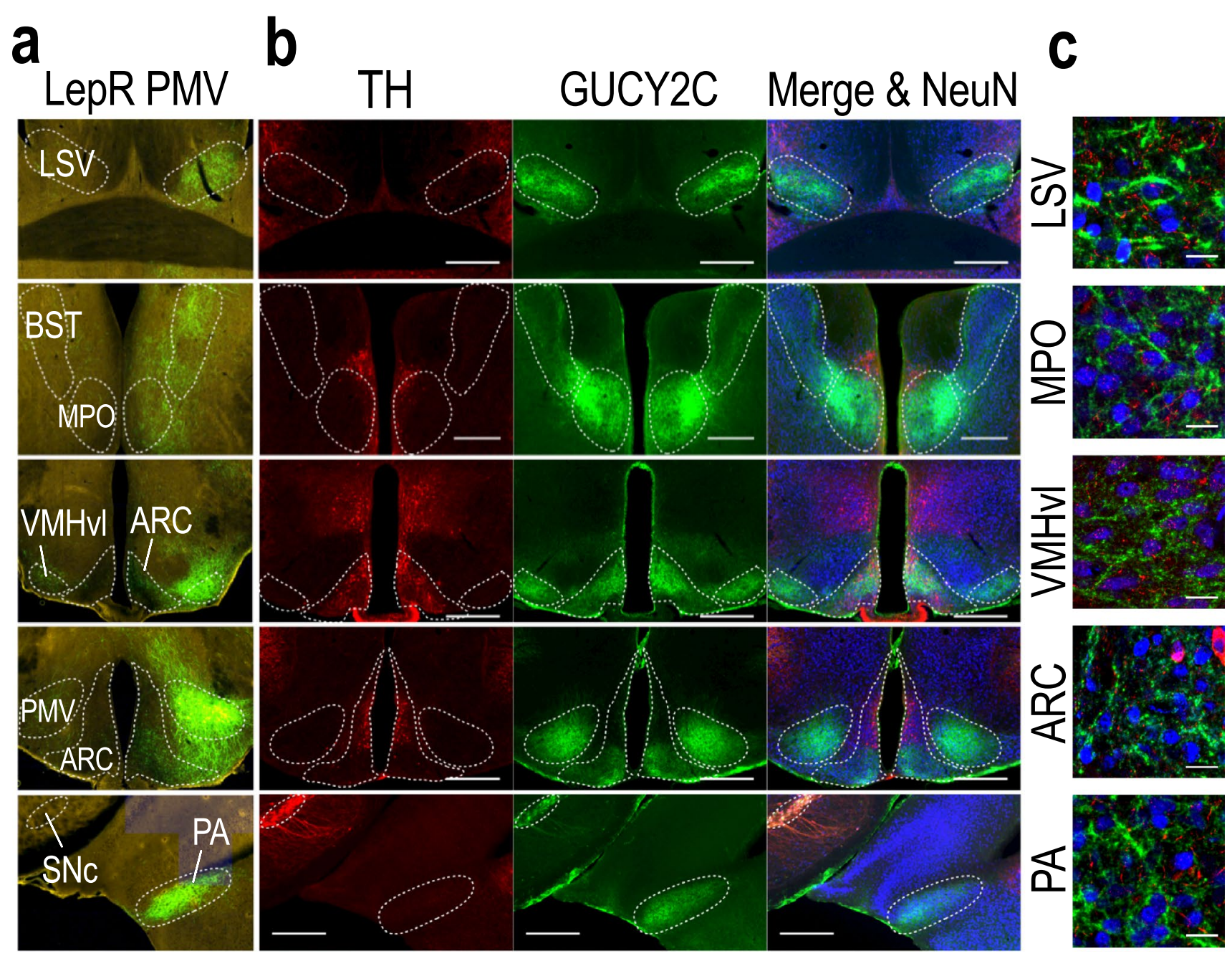

Fig. 3 PMV LepR projection sites express GUCY2C protein in projections. a Unilateral stereotaxic injection of cre-inducible GFP AAV into the PMV of LepR-cre mice reveals GFP(+) projections in hypothalamic and extrahypothalamic nuclei (Allen Institute for Brain Science, experiment ID 167656388) (Oh et al. 2014). b GUCY2C is expressed in PMV projection sites of LepR neurons, but not with TH. c High magnification reveals that GUCY2C protein is expressed in projections, not neuronal cell bodies in hypothalamic nuclei other than the PMV. Scale bars in b: $200 \mu \mathrm{m}$; in c $20 \mu \mathrm{m}$. $L S V$ lateral septal nucleus, ventral part, $B S T$ bed nucleus of the stria terminalis, $M P O$ medial preoptic nucleus, $v l$ ventrolateral aspect of the ventromedial hypothalamus, $A R C$ arcuate nucleus, $S N c$ substantia nigra, pars

effects on feeding (Folgueira et al. 2016a; Kim et al. 2016; Valentino et al. 2011). Conversely, eliminating the expression of uroguanylin or GUCY2C, or neutralizing circulating uroguanylin with an antibody, blocks these behavioral effects (Begg et al. 2014; Kim et al. 2016; Valentino et al. 2011). Further, central administration of uroguanylin, genetically or pharmacologically, recapitulates these effects on feeding (Folgueira et al. 2016a; Kim et al. 2016; Valentino et al. 2011). Moreover, beyond feeding, central administration of GUCY2C ligands induce metabolic changes in brown and compacta, $P A$ posterior amygdalar nucleus Source images for a can be found at the following links: http://connectivity.brain-map.org/ projection/experiment/siv/167656152?imageId=167656303\&image Type=TWO_PHOTON. http://connectivity.brain-map.org/proje ction/experiment/siv/167656152?image Id=167656319\&image Type=TWO_PHOTON. http://connectivity.brain-map.org/proje ction/experiment/siv/167656152?image Id=167656392\&image Type=TWO_PHOTON. http://connectivity.brain-map.org/proje ction/experiment/siv/167656152?imageId=167656404\&image Type=TWO_PHOTON. http://connectivity.brain-map.org/proje ction/experiment/siv/167656152?image Id=167656434\&image Type=TWO_PHOTON

white fat, and enhance GI transit, contributing to metabolic and body weight homeostasis (Folgueira et al. 2016a; Rodriguez et al. 2016).

While these pleiotropic responses, modulating both physiology and behavior, are mediated by neurons expressing GUCY2C (Kim et al. 2016; Valentino et al. 2011; Folgueira et al. 2016b), the precise circuits regulating those processes remain undefined. Here, identification of neurons that coexpress LepRs provides the first structural basis for signaling interactions between leptin and GUCY2C hormone axes. 


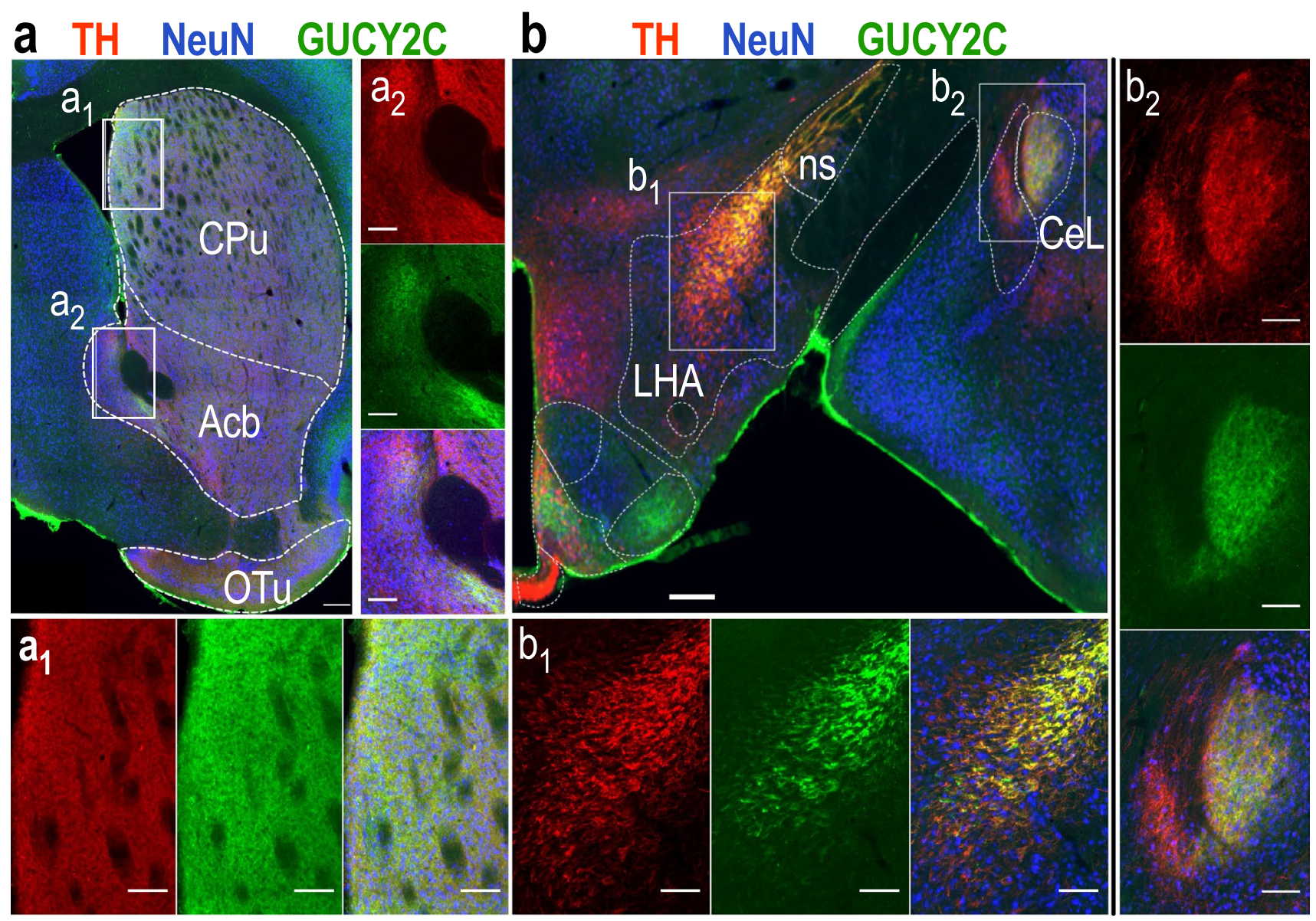

Fig. 4 GUCY2C protein is expressed in projection sites of dopaminergic midbrain neurons. GUCY2C protein expression in the Caudoputamen (a1), nucleus Accumbens (a2), lateral hypothalamic area (b1), nigrostriatal tract (b1), and lateral part of the central amygdalar

Previous studies revealed that ingestion of food-induced endocrine secretion of prouroguanylin in a leptin-dependent fashion (Folgueira et al. 2016b). In the absence of leptin, prouroguanylin expression in intestine and release into the circulation by food was suppressed. Conversely, in leptindeficient mice, replacement of leptin reconstituted prouroguanylin expression and food-induced release into the circulation. Beyond these effects on prouroguanylin secretion and the afferent limb of this endocrine axis, results here support a potential role for interactions between LepR and GUCY2C signaling axes in regulating efferent outputs from the hypothalamus. This possibility is underscored by the selective and coincident concentration of both GUCY2C and LepRs in the PMV (Patterson et al. 2011). Moreover, it is highlighted by the similarities in behavioral and metabolic effects of these endocrine systems, including suppression of appetite and satiety, feeding, and adipose metabolism that are integrated to maintain body weight and obesity (Rosenbaum and Leibel 2014). nucleus (CeL) (b2) co-localized with TH. $C P u$ caudoputamen, $A c b$ nucleus accumbens, $O T$ olfactory tubercle, $n s$ nigrostriatal tract, $L H A$ lateral hypothalamic area, $C e L$ lateral part of the central amygdalar nucleus. Scale bars: $500 \mu \mathrm{m}(\mathbf{a}, \mathbf{b})$, or $50 \mu \mathrm{m}$ (insets)

Interestingly, the source of hypothalamic GUCY2C protein, the PMV, integrates metabolism and energy balance with reproduction (Donato 2011; Leshan 2014). For example, leptin signaling in the female PMV regulates puberty onset and ovulation, ensuring adequate energy stores for the energy-intensive process of pregnancy and rearing (Donato 2011; Donato 2009). However, the PMV is not only a passive acceptor of energy balance; it also mediates sex hormonedependent changes in food intake, although the mechanism underlying this is not clear (Donato 2009; Leshan 2009). Further studies are required to explore the potential role of GUCY2C signaling in regulating food intake in the context of reproduction.

Expression of mRNA and protein in neuronal cell bodies, but protein without mRNA in projections and synapses at distant sites, suggests that GUCY2C is transcribed and translated centrally and transported to distant nerve terminals. In turn, these observations provide a structural basis supporting the suggestion that GUCY2C-cGMP signaling 

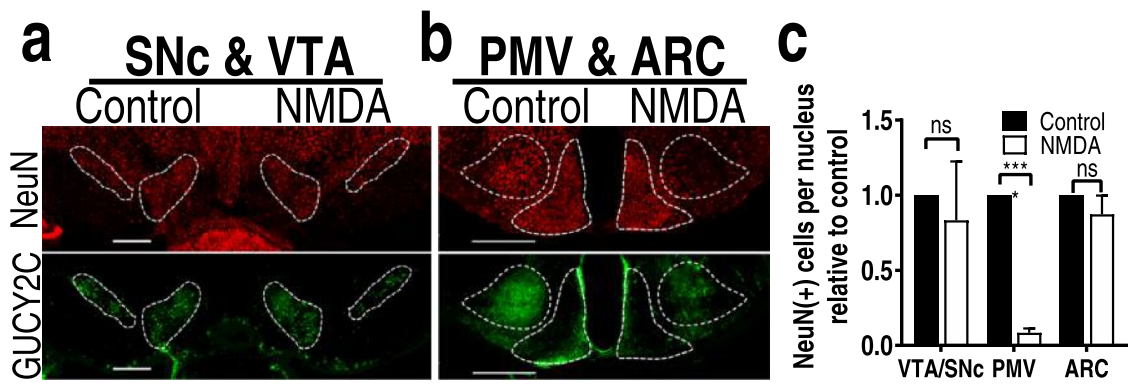

d
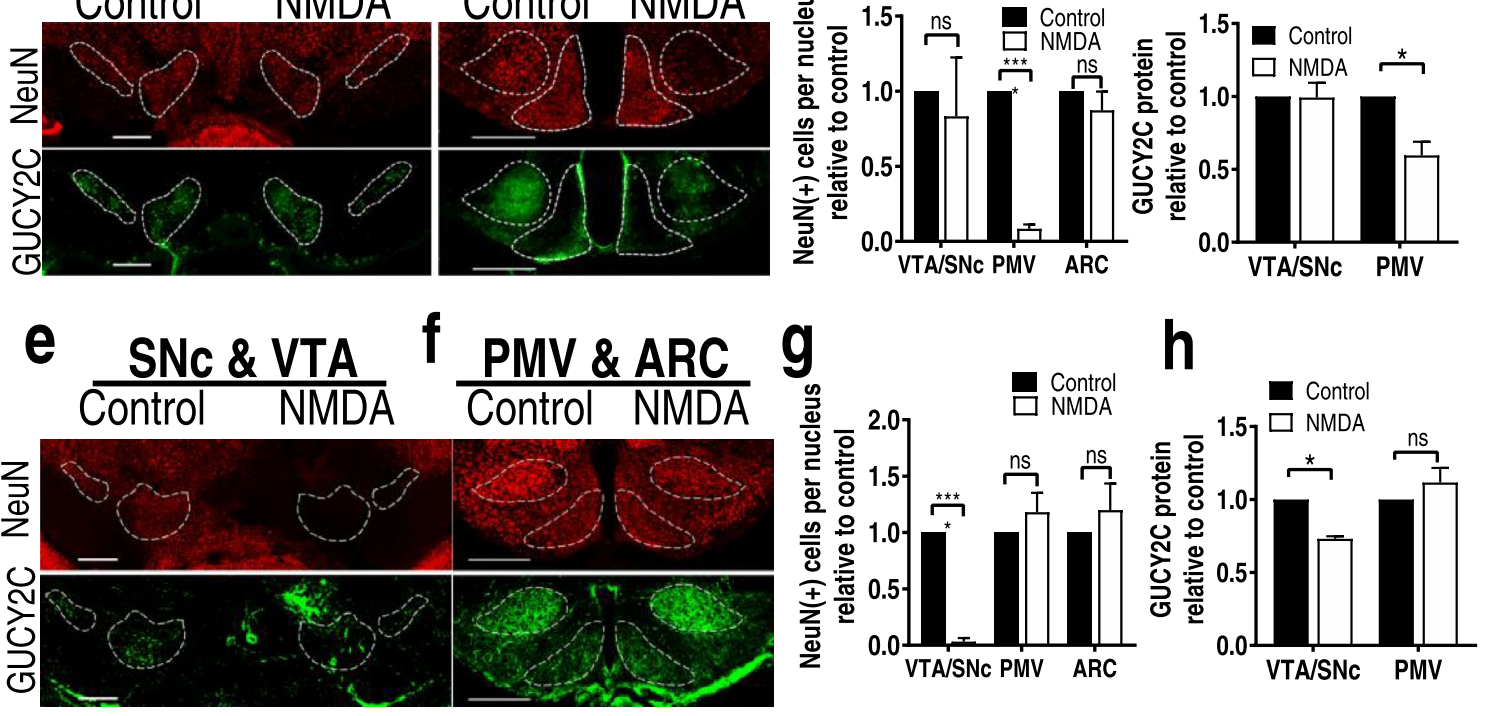

Fig. 5 Selective stereotaxic ablation of the PMV or VTA/SNc with NMDA reduced GUCY2C-immunofluorescent neurons specifically in the targeted region. a Representative unilateral ablation of PMV with NMDA did not affect neurons or GUCY2C immunofluorescence in the SNc or VTA. b In contrast to the control side (left), NMDA injection eliminated neurons in the PMV, but not in the ARC. c Stereotaxic PMV ablation with NMDA significantly reduced the number of neurons $[\mathrm{NeuN}(+)$ cells] in the PMV, without reducing the number of neurons in the SN/VTA or arcuate nucleus. d Quantification of GUCY2C protein expression in nuclei expressing GUCY2C $(+)$ cell bodies revealed that unilateral PMV ablation eliminated GUCY2C protein expression in the PMV, but not in the VTA

modulates synaptic transmission integrating complex behavioral and homeostatic mechanisms controlling feeding and metabolism (Folgueira et al. 2018; Seeley and Tschop 2011). In that context, GUCY2C expressed in dopaminergic neurons potentiated their excitation by metabotropic glutamate and acetylcholine signaling (Gong et al. 2011). Together with diminished basal levels of striatal dopamine in Gucy $2 c^{-/-}$mice, these observations suggest that midbrain GUCY2C regulates dopamine release (Gong et al. 2011). Further, cGMP-dependent protein kinase is expressed in presynaptic terminals in the Acb, where it stimulates dopamine release (Lee et al. 2013; Jouvert et al. 2004). In addition, cGMP-mediated opening of presynaptic CNG channels induces presynaptic depolarization and $\mathrm{Ca}^{+2}$ entry, resulting in action potential-independent neurotransmitter release (Barnstable et al. 2004; Zufall et al. 1997). Moreover, cGMP signaling also has been implicated in synaptogenesis, through presynaptic PKG-mediated VASP phosphorylation (Feil and Kleppisch 2008; Wang et al. 2005). Taken together, transport of GUCY2C along axonal projections emanating from the PMV and VTA/SNc to nerve terminals in distant nuclei provides a structural framework supporting or SNc; $n=2$ mice. e Unilateral injection of NMDA into the VTA/ SNc severely diminished GUCY2C-expressing neurons in the VTA/ $\mathrm{SNc}$ while sparing VTA/SNc neurons on the control side. f NMDA injection into the VTA/SNc did not affect neurons in the PMV or ARC. g Stereotaxic VTA/SNc ablation with NMDA significantly reduced the number of neurons in the VTA/SNc, but not the PMV or ARC. $\mathbf{h}$ Quantification of GUCY2C protein expression in nuclei expressing $\mathrm{GUCY} 2 \mathrm{C}(+)$ cell bodies revealed that unilateral VTA/ SNc ablation eliminated GUCY2C expression in the VTA/SNc, but not the PMV or ARC. Scale bars in a, b, e, and f: $200 \mu \mathrm{m} ;{ }^{*} p<0.05$; $* * * * p<0.0001$

a functional role for this signaling axis in modulating synaptic transmission integrating complex behavioral and homeostatic functions.

Cyclic GMP regulates feeding behaviors, including nutrient acquisition and satiety, broadly across diverse phylogenetic categories, including worms, flies, bees, and ants (Kaun et al. 2007b). For example, in Drosophila cGMP signaling opposes feeding following nutrient deprivation, an invertebrate behavior equivalent to mammalian satiety (Kaun et al. 2007a; Kaun et al. 2007b). In C. elegans cGMP mediates quiescence, the termination of feeding that is a behavior homologous to satiety in mammals (You et al. 2008). Indeed, as in mammals, satiety in C. elegans is regulated by a membrane-bound guanylyl cyclase produced by specific neurons that regulate eating. Loss of cGMP signaling in C. elegans eliminates appetite regulation, with ingestion of excess nutrients and fat deposition. In the present study, these observations are expanded to reveal the existence of GUCY2C circuits which are conserved in mice and humans in hypothalamus and midbrain, centers that canonically regulate metabolic homeostasis, satiety, and behaviors associated with feeding (Berthoud et al. 2017; 


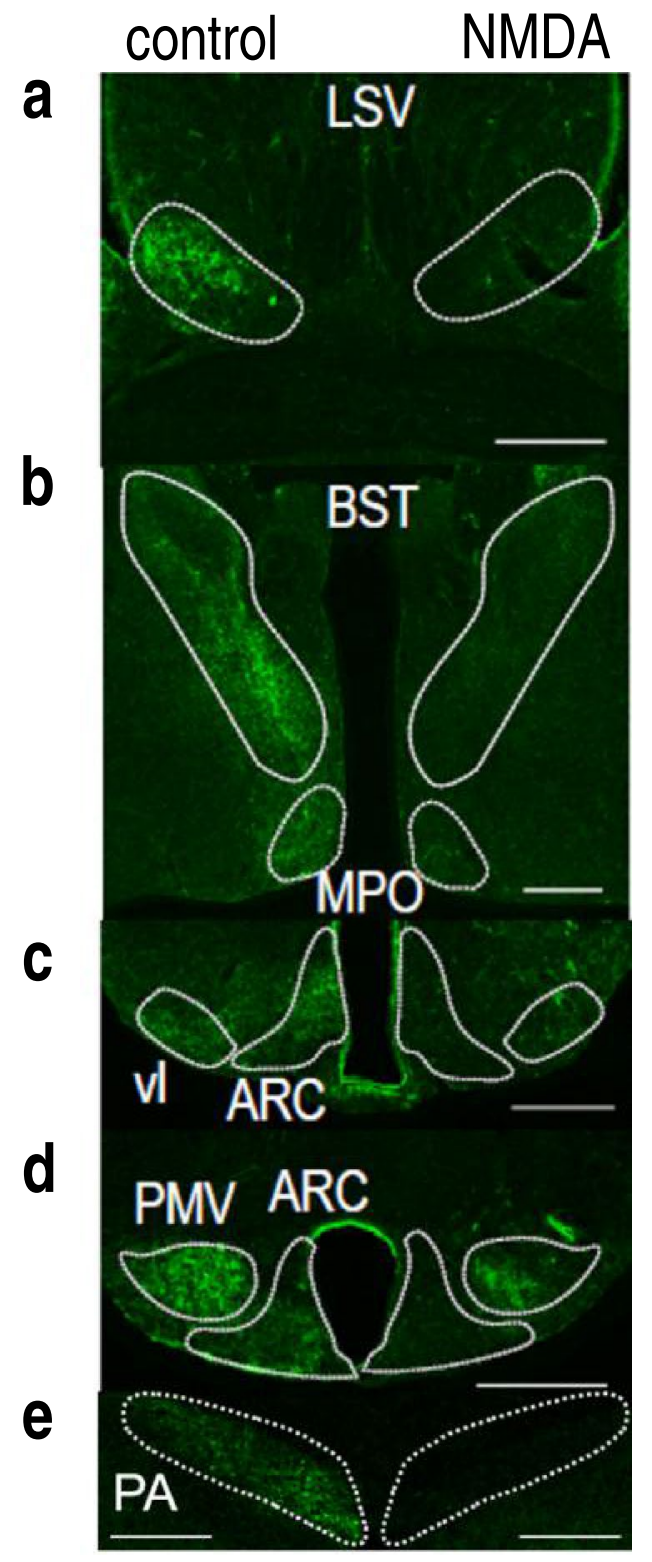

Fig. 6 Selective stereotaxic ablation of the PMV or VTA/SNc with NMDA eliminated GUCY2C immunofluorescence specifically in distant projections from the targeted region. NMDA ablation of the PMV eliminated GUCY2C immunofluorescence in projections from the PMV: a LSV, b BST and MPO, c vl and rostral ARC, d PMV and caudal ARC, and e PA. Conversely, NMDA ablation of the VTA eliminated GUCY2C immunofluorescence in projections from the VTA: f CPu, Acb, and OT, and $\mathbf{g}$ LHA, ns, and CeL. NMDA ablation of the PMV (h) or VTA/SNc (i) produced selective loss of GUCY2C protein expression in regions canonically associated with projections from these nuclei, respectively. Data in $\mathbf{h}$ and $\mathbf{i}$ represent GUCY2C protein expression normalized to the contralateral control side. For $\mathbf{h}$,

Munzberg et al. 2016). This evolutionary conservation of neuronal cGMP circuits broadly across phyla, from worms to man, underscores the enduring framework provided by this mechanism to integrate the essential functions of feeding and metabolism in multicellular organisms.

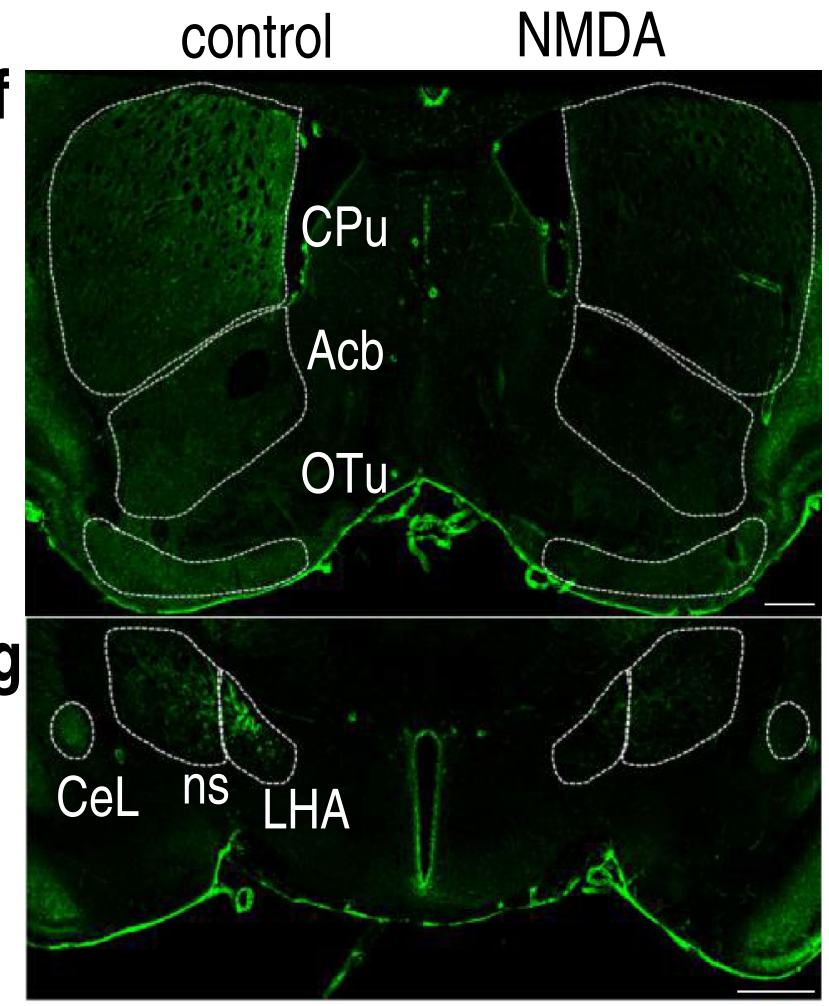

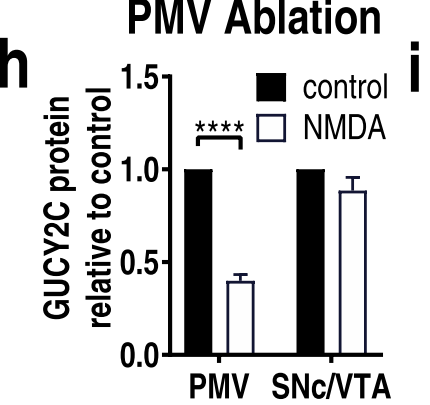

Source of Projections
SNc/VTA Ablation

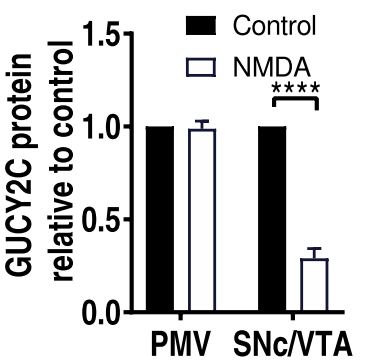

Source of Projections data were collected from 2 mice with PMV ablation in the absence of neuronal loss in the arcuate nucleus, SNc, or VTA. For i, data were collected from 2 mice with VTA/SNc ablation in the absence of neuronal loss in the PMV or arcuate nucleus. $L S V$ lateral septal nucleus, ventral part, $B S T$ bed nucleus of the stria terminalis, MPO medial preoptic nucleus, $v l$ ventromedial hypothalamus, ventrolateral part, $A R C$ arcuate nucleus, $P M V$ ventral premammillary nucleus, $P A$ posterior amygdalar nucleus, $C P u$ caudoputamen, $A c b$ nucleus accumbens, $O T$ olfactory tubercle, $n s$ nigrostriatal tract, $L H A$ lateral hypothalamic area, $C e L$ lateral part of the central amygdalar nucleus. Scale bars in a-g: $200 \mu \mathrm{m} . * * * * p<0.0001$

Distinct neuronal subpopulations in hypothalamus and midbrain that project to multiple sites in the brain highlight a potential role for the GUCY2C endocrine hormone axis in complex mechanisms integrating distinct components of metabolic homeostasis and hedonic behaviors governing 


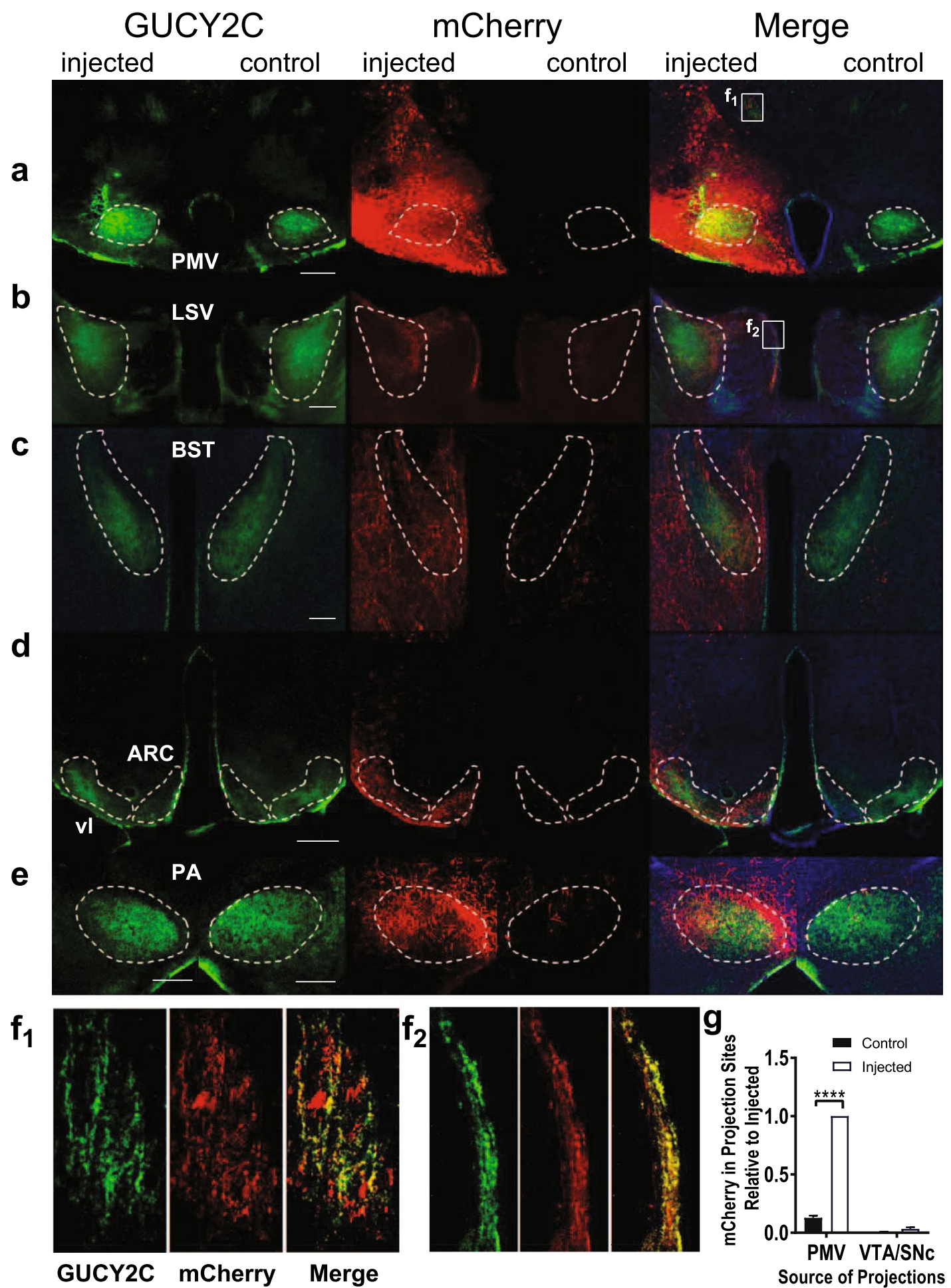

Fig.7 Selective anterograde tracing localized GUCY2C protein expression in PMV axons projecting to distant canonical regions. a Unilateral injection of AAV2-mCherry into the PMV produced mCherry expression in GUCY2C(+) neurons. b-e mCherry was coexpressed with GUCY2C in canonical ipsilateral projection sites of the PMV, including the b LSV, $\mathbf{c}$ BST, d ARC and vl, and e PA. $\mathrm{f}_{1}$, $\mathrm{f}_{2}$ GUCY2C(+) axons from the PMV also expressed mCherry from infected PMV neurons both near the PMV $\left(\mathrm{f}_{1}\right)$ and distally leading into the LSV $\left(\mathrm{f}_{2}\right)$. g mCherry was quantitatively expressed in ipsi- lateral GUCY2C(+) projection sites of the PMV, but not in those of the VTA/SNc. Data in $\mathbf{g}$ represents mCherry expression normalized to maximum mCherry expression in each image. Data was collected from 2 mice with injection of mCherry into the PMV that spared the VTA/SNc. $L S V$ lateral septal nucleus, ventral part, $B S T$ bed nucleus of the stria terminalis, $v l$ ventromedial hypothalamus, ventrolateral part, $A R C$ arcuate nucleus, $P M V$ ventral premammillary nucleus, $P A$ posterior amygdalar nucleus. Scale bars in a-e $200 \mu \mathrm{m}, \mathrm{f}_{1}, \mathrm{f}_{2} 50 \mu \mathrm{m}$. $* * * * p<0.0001$ 


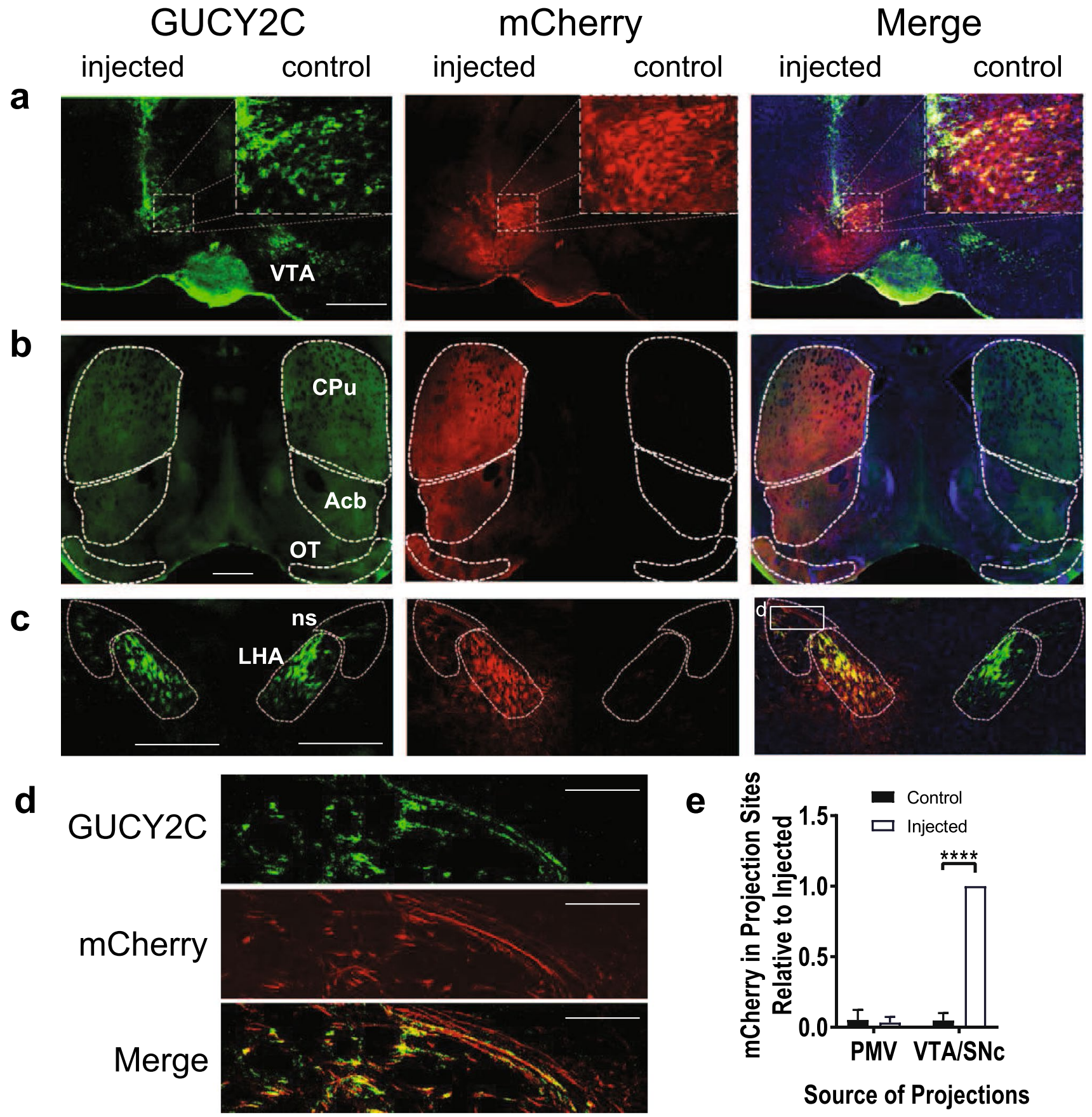

Fig. 8 Selective anterograde tracing localized GUCY2C protein expression in VTA/SNc axons projecting to distant canonical regions. a Unilateral injection of AAV2-mCherry into the VTA produced mCherry expression in $\mathrm{GUCY} 2 \mathrm{C}(+)$ neurons. b, c mCherry was co-expressed with GUCY2C in canonical ipsilateral projection sites of the VTA including the $\mathbf{b} \mathrm{CPu}, \mathrm{Acb}$, and OT and $\mathbf{c}$ LHA and ns. d GUCY2C(+) axons from the VTA traveling in the ns express mCherry. e mCherry was quantitatively expressed in ipsilateral
GUCY2C(+) projection sites of the VTA/SNc, but not in those of the PMV. Data in e represents mCherry expression normalized to maximum mCherry expression in each image. Data were collected from 2 mice with injection of mCherry into the VTA/SNc that spared the PMV. $C P u$ caudoputamen, $A c b$ nucleus accumbens, $O T$ olfactory tubercle, $n s$ nigrostriatal tract, $L H A$ lateral hypothalamic area. Scale bars in a-c $200 \mu \mathrm{m}, \mathbf{d} 100 \mu \mathrm{m} . * * * * p<0.0001$ 


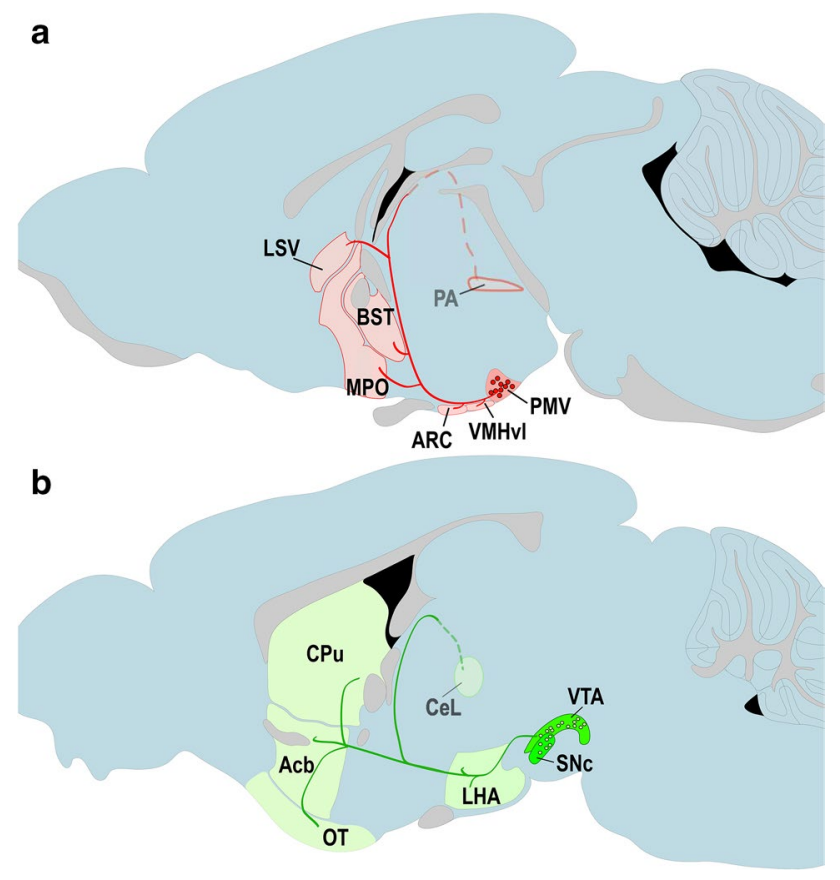

Fig. 9 Proposed circuitry of GUCY2C neurons in the central nervous system. a Proposed circuitry of the GUCY2C PMV circuit, which includes GUCY2C mRNA and protein in neuronal cell bodies (red circles) in the PMV, as well as protein in axonal projections (red lines) and terminals to other regions of the brain (red shaded regions). b Proposed circuitry of the GUCY2C VTA/SNc circuit, with TH(+), GUCY2C-expressing cell bodies (green circles) in the VTA and SNc, and projections to the $\mathrm{LHA}, \mathrm{CeL}, \mathrm{CPu}, \mathrm{Acb}$, and $\mathrm{OTu}$

food acquisition (Mogenson et al. 1980). Feeding, in part, consists of discrete complex behavior, initiating with the conscious desire to feed, followed by directed behaviors to seek out and approach food, before engaging in the stereotyped motor activities of biting, chewing, and swallowing (Watts 2000). Termination of eating represents the final phase of feeding induced by satiety, or alternate competing drives, such as sleeping, mating, or evading predation (Berthoud 2002). Across these phases, there is continuous central integration of internal and external information, including the diurnal clock, energy stores, and postprandial gut hormone levels to influence the incentive salience of feeding, drive decision-making, and influence behavior. In that context, two distinct circuits in the brain integrate these signals to regulate feeding (Lutter and Nestler 2009; Saper et al. 2002). The homeostatic circuit drives energy balance and involves the brainstem and hypothalamus (Efeyan et al. 2015; Betley et al. 2013). The hedonic circuit focuses on rewards associated with feeding and signals through midbrain dopaminergic neurons and the striatum (Kenny 2011; Sohn et al. 2013). In that context, studies here provide the first structural framework supporting a role for the GUCY2C hormone axis in integrating signals from these different circuits that play principle roles in regulating food acquisition behaviors and feeding. Much like the leptin hormone axis integrates afferent signals from peripheral energy depots (e.g., adipose tissue) to guide feeding in homeostatic and hedonic circuits, uroguanylin and GUCY2C may encode energy availability and feeding status from the gut to centrally integrate modulation of calorie consumption (Folgueira et al. 2016b; Figlewicz 2016; Thompson and Borgland 2013; Scott et al. 2011; Valentino et al. 2011; Perry et al. 2010; Leinninger et al. 2009; Hommel et al. 2006; Balthasar et al. 2004).

In summary, the present studies reveal transcription and translation of GUCY2C in neurons that form two independent circuits in brain, including in the PMV in the hypothalamus, involving LepR(+) neurons, and in the VTA/SNc in the midbrain, involving $\mathrm{TH}(+)$ dopaminergic neurons, in mice and humans. In turn, these neurons deploy axons that contain GUCY2C and synapse in distal non-overlapping nuclei. These distributed circuits provide a structural framework that may underlie the functional integration of homeostatic and hedonic signaling, in hypothalamus and midbrain, respectively, controlling feeding behaviors and the consumption of calories (Berthoud et al. 2017). Moreover, distribution of GUCY2C to axons and synapses may form the structural basis for the established role of neuronal GUCY2C in mediating anorexigenic signaling, including the production of POMC and downstream activation of neuronal firing marked by c-Fos expression (Kim et al. 2016; Valentino et al. 2011). These newly identified circuits support the potential utility of GUCY2C as a novel therapeutic target to prevent and treat obesity. This suggestion is underscored by the suppression of uroguanylin expression silencing central GUCY2C by hyperphagia in obesity, suggesting that obesity is, at least in part, an endocrine disease of GUCY2C hormone insufficiency (Kim et al. 2016). The ability to translate these observations into therapies is highlighted by the recent approval of the GUCY2C ligands linaclotide and plecanatide to treat chronic constipation syndromes (Waldman and Camilleri 2018).

Acknowledgements We would like to thank Dr. George Smith for kindly providing the AAV2-mCherry vector.

Funding Supported by grants from NIH (1R01 CA204881, R01 CA206026, P30 CA56036 to SAW; 2R01NS079702, 1R56NS096028 to ACL, 1R01NS110084-01 to RJS), Targeted Diagnostics and Therapeutics Inc., Pharmaceutical Research and Manufacturers of America (PhRMA) Foundation (to AES), W.W. Smith Charitable Trust (to AES), and Margaret Q. Landenberger Research Foundation (to AES). D.M. and J.R. were supported by Predoctoral Fellowship Awards in Pharmacology and Toxicology from the PhRMA Foundation. DJM (1F30DK103492) and BAC (F30NS103436) were supported by Ruth L. Kirschstein National Research Service Awards. SAW is the Samuel MV Hamilton Professor of Medicine at Thomas Jefferson University. 


\section{Compliance with ethical standards}

Conflict of interest SAW is the Chair of the Scientific Advisory Board and member of the Board of Directors (both uncompensated) of Targeted Diagnostics \& Therapeutics, Inc. which provided research funding that, in part, supported this work and has a license to commercialize inventions related to this work. $\mathrm{He}$ is a member of the Scientific Advisory Boards of Therapeutic Architects, Inc. and MLH Exploration, LLC (both uncompensated). He is a member of the Board of Directors of Feelux, Inc. (compensated).

Research involving human participants and/or animals Human samples were provided by the Brain Tissue Donation Program at the University of Pittsburgh, via the NIH NeuroBioBank (IRB protocol \# REN14120157/IRB981146). Additionally, the Institutional Animal Care and Use Committee at Thomas Jefferson University approved all animal studies described in this work.

\section{References}

Balthasar N, Coppari R, McMinn J, Liu SM, Lee CE, Tang V, Kenny CD, McGovern RA, Chua SC Jr, Elmquist JK, Lowell BB (2004) Leptin receptor signaling in POMC neurons is required for normal body weight homeostasis. Neuron 42(6):983-991. https://doi. org/10.1016/j.neuron.2004.06.004

Barnstable CJ, Wei JY, Han MH (2004) Modulation of synaptic function by cGMP and cGMP-gated cation channels. Neurochem Int 45(6):875-884. https://doi.org/10.1016/j.neuint.2004.03.018

Begg DP, Steinbrecher KA, Mul JD, Chambers AP, Kohli R, Haller A, Cohen MB, Woods SC, Seeley RJ (2014) Effect of guanylate cyclase-C activity on energy and glucose homeostasis. Diabetes 63(11):3798-3804. https://doi.org/10.2337/db14-0160

Beier KT, Steinberg EE, DeLoach KE, Xie S, Miyamichi K, Schwarz L, Gao XJ, Kremer EJ, Malenka RC, Luo L (2015) Circuit architecture of VTA dopamine neurons revealed by systematic inputoutput mapping. Cell 162(3):622-634. https://doi.org/10.1016/j. cell.2015.07.015

Berkseth KE, Guyenet SJ, Melhorn SJ, Lee D, Thaler JP, Schur EA, Schwartz MW (2014) Hypothalamic gliosis associated with highfat diet feeding is reversible in mice: a combined immunohistochemical and magnetic resonance imaging study. Endocrinology 155(8):2858-2867. https://doi.org/10.1210/en.2014-1121

Berthoud HR (2002) Multiple neural systems controlling food intake and body weight. Neurosci Biobehav Rev 26(4):393-428

Berthoud HR, Munzberg H, Morrison CD (2017) Blaming the brain for obesity: integration of hedonic and homeostatic mechanisms. Gastroenterology 152(7):1728-1738. https://doi.org/10.1053/j. gastro.2016.12.050

Betley JN, Cao ZF, Ritola KD, Sternson SM (2013) Parallel, redundant circuit organization for homeostatic control of feeding behavior. Cell 155(6):1337-1350. https://doi.org/10.1016/j.cell.2013.11.002

Canteras NS, Simerly RB, Swanson LW (1992) Projections of the ventral premammillary nucleus. J Comp Neurol 324(2):195-212. https://doi.org/10.1002/cne.903240205

Clemmensen C, Muller TD, Woods SC, Berthoud HR, Seeley RJ, Tschop MH (2017) Gut-brain cross-talk in metabolic control. Cell 168(5):758-774. https://doi.org/10.1016/j.cell.2017.01.025

Di Guglielmo MD, Perdue L, Adeyemi A, van Golen KL, Corao DU (2017) Immunohistochemical staining for uroguanylin, a satiety hormone, is decreased in intestinal tissue specimens from female adolescents with obesity. Pediatr Dev Pathol. https://doi. org/10.1177/1093526617722912
Di Guglielmo MD, Tonb D, He Z, Adeyemi A, van Golen KL (2018) Pilot study measuring the novel satiety hormone, pro-uroguanylin, in adolescents with and without obesity. J Pediatr Gastroenterol Nutr 66(3):489-495. https://doi.org/10.1097/MPG.00000 00000001796

Donato J Jr, Silva RJ, Sita LV, Lee S, Lee C, Lacchini S, Bittencourt JC, Franci CR, Canteras NS, Elias CF (2009) The ventral premammillary nucleus links fasting-induced changes in leptin levels and coordinated luteinizing hormone secretion. J Neurosci 29(16):5240-5250. https://doi.org/10.1523/JNEUR OSCI.0405-09.2009

Donato J Jr, Cravo RM, Frazao R, Gautron L, Scott MM, Lachey J, Castro IA, Margatho LO, Lee S, Lee C, Richardson JA, Friedman J, Chua S Jr, Coppari R, Zigman JM, Elmquist JK, Elias CF (2011) Leptin's effect on puberty in mice is relayed by the ventral premammillary nucleus and does not require signaling in Kiss1 neurons. J Clin Investig 121(1):355-368. https://doi. org/10.1172/JCI45106

Donato J Jr, Lee C, Ratra DV, Franci CR, Canteras NS, Elias CF (2013) Lesions of the ventral premammillary nucleus disrupt the dynamic changes in Kiss 1 and GnRH expression characteristic of the proestrus-estrus transition. Neuroscience 241:67-79. https://doi.org/10.1016/j.neuroscience.2013.03.013

Efeyan A, Comb WC, Sabatini DM (2015) Nutrient-sensing mechanisms and pathways. Nature 517(7534):302-310. https://doi. org/10.1038/nature 14190

Feil R, Kleppisch T (2008) NO/cGMP-dependent modulation of synaptic transmission. Handb Exp Pharmacol 184:529-560. https ://doi.org/10.1007/978-3-540-74805-2_16

Figlewicz DP (2016) Expression of receptors for insulin and leptin in the ventral tegmental area/substantia nigra (VTA/SN) of the rat: Historical perspective. Brain Res 1645:68-70. https://doi. org/10.1016/j.brainres.2015.12.041

Folgueira C, Beiroa D, Callon A, Al-Massadi O, Barja-Fernandez S, Senra A, Ferno J, Lopez M, Dieguez C, Casanueva FF, RohnerJeanrenaud F, Seoane LM, Nogueiras R (2016a) Uroguanylin action in the brain reduces weight gain in obese mice via different efferent autonomic pathways. Diabetes 65(2):421-432. https ://doi.org/10.2337/db15-0889

Folgueira C, Sanchez-Rebordelo E, Barja-Fernandez S, Leis R, Tovar S, Casanueva FF, Dieguez C, Nogueiras R, Seoane LM (2016b) Uroguanylin levels in intestine and plasma are regulated by nutritional status in a leptin-dependent manner. Eur J Nutr 55(2):529-536. https://doi.org/10.1007/s00394-015-0869-2

Folgueira C, Barja-Fernandez S, Gonzalez-Saenz P, Pena-Leon V, Castelao C, Ruiz-Pinon M, Casanueva FF, Nogueiras R, Seoane LM (2018) Uroguanylin: a new actor in the energy balance movie. J Mol Endocrinol 60(2):R31-R38. https://doi. org/10.1530/JME-17-0263

Frick GS, Pitari GM, Weinberg DS, Hyslop T, Schulz S, Waldman SA (2005) Guanylyl cyclase C: a molecular marker for staging and postoperative surveillance of patients with colorectal cancer. Expert Rev Mol Diagn 5(5):701-713. https://doi. org/10.1586/14737159.5.5.701

Gong R, Ding C, Hu J, Lu Y, Liu F, Mann E, Xu F, Cohen MB, Luo M (2011) Role for the membrane receptor guanylyl cyclase$\mathrm{C}$ in attention deficiency and hyperactive behavior. Science 333(6049):1642-1646. https://doi.org/10.1126/science.1207675

Hommel JD, Trinko R, Sears RM, Georgescu D, Liu ZW, Gao XB, Thurmon JJ, Marinelli M, DiLeone RJ (2006) Leptin receptor signaling in midbrain dopamine neurons regulates feeding. Neuron 51(6):801-810. https://doi.org/10.1016/j.neuro n.2006.08.023

Hopman AH, Ramaekers FC, Speel EJ (1998) Rapid synthesis of biotin-, digoxigenin-, trinitrophenyl-, and fluorochrome-labeled tyramides and their application for In situ hybridization using CARD 
amplification. J Histochem Cytochem 46(6):771-777. https://doi. org/10.1177/002215549804600611

Jouvert P, Revel MO, Lazaris A, Aunis D, Langley K, Zwiller J (2004) Activation of the cGMP pathway in dopaminergic structures reduces cocaine-induced EGR-1 expression and locomotor activity. J Neurosci 24(47):10716-10725. https://doi.org/10.1523/ JNEUROSCI.1398-04.2004

Kasukawa T, Masumoto KH, Nikaido I, Nagano M, Uno KD, Tsujino K, Hanashima C, Shigeyoshi Y, Ueda HR (2011) Quantitative expression profile of distinct functional regions in the adult mouse brain. PLoS One 6(8):e23228. https://doi.org/10.1371/ journal.pone. 0023228

Kaun KR, Hendel T, Gerber B, Sokolowski MB (2007a) Natural variation in Drosophila larval reward learning and memory due to a cGMP-dependent protein kinase. Learn Mem 14(5):342-349. https://doi.org/10.1101/lm.505807

Kaun KR, Riedl CA, Chakaborty-Chatterjee M, Belay AT, Douglas SJ, Gibbs AG, Sokolowski MB (2007b) Natural variation in food acquisition mediated via a Drosophila cGMP-dependent protein kinase. J Exp Biol 210(Pt 20):3547-3558. https://doi.org/10.1242/ jeb.006924

Kenny PJ (2011) Reward mechanisms in obesity: new insights and future directions. Neuron 69(4):664-679. https://doi. org/10.1016/j.neuron.2011.02.016

Kim MH, Jee JH, Park S, Lee MS, Kim KW, Lee MK (2014) Metformin enhances glucagon-like peptide 1 via cooperation between insulin and Wnt signaling. J Endocrinol 220(2):117-128. https:// doi.org/10.1530/JOE-13-0381

Kim GW, Lin JE, Snook AE, Aing AS, Merlino DJ, Li P, Waldman SA (2016) Calorie-induced ER stress suppresses uroguanylin satiety signaling in diet-induced obesity. Nutr Diabetes 6:e211. https:// doi.org/10.1038/nutd.2016.18

Kopelman P (2007) Health risks associated with overweight and obesity. Obesity Rev 8(Suppl 1):13-17. https://doi.org/10.1111/ j.1467-789X.2007.00311.x

Kuhn M (2016) Molecular physiology of membrane guanylyl cyclase receptors. Physiol Rev 96(2):751-804. https://doi.org/10.1152/ physrev.00022.2015

Lee DK, Oh JH, Yang JH, Youn B, Shim YB, Shim I, Wang JQ, Choe ES (2013) Protein kinase G linked to dopamine D3 receptors in the dorsal striatum controls dopamine release, DeltaFosB expression and locomotor activity after repeated cocaine administration. Neurosci Lett 541:120-125. https://doi.org/10.1016/j.neule t.2013.02.014

Lein ES, Hawrylycz MJ, Ao N, Ayres M, Bensinger A, Bernard A, Boe AF, Boguski MS, Brockway KS, Byrnes EJ, Chen L, Chen L, Chen TM, Chin MC, Chong J, Crook BE, Czaplinska A, Dang CN, Datta S, Dee NR, Desaki AL, Desta T, Diep E, Dolbeare TA, Donelan MJ, Dong HW, Dougherty JG, Duncan BJ, Ebbert AJ, Eichele G, Estin LK, Faber C, Facer BA, Fields R, Fischer SR, Fliss TP, Frensley C, Gates SN, Glattfelder KJ, Halverson KR, Hart MR, Hohmann JG, Howell MP, Jeung DP, Johnson RA, Karr PT, Kawal R, Kidney JM, Knapik RH, Kuan CL, Lake JH, Laramee AR, Larsen KD, Lau C, Lemon TA, Liang AJ, Liu Y, Luong LT, Michaels J, Morgan JJ, Morgan RJ, Mortrud MT, Mosqueda NF, Ng LL, Ng R, Orta GJ, Overly CC, Pak TH, Parry SE, Pathak SD, Pearson OC, Puchalski RB, Riley ZL, Rockett HR, Rowland SA, Royall JJ, Ruiz MJ, Sarno NR, Schaffnit K, Shapovalova NV, Sivisay T, Slaughterbeck CR, Smith SC, Smith KA, Smith BI, Sodt AJ, Stewart NN, Stumpf KR, Sunkin SM, Sutram M, Tam A, Teemer CD, Thaller C, Thompson CL, Varnam LR, Visel A, Whitlock RM, Wohnoutka PE, Wolkey CK, Wong VY, Wood M, Yaylaoglu MB, Young RC, Youngstrom BL, Yuan XF, Zhang B, Zwingman TA, Jones AR (2007) Genome-wide atlas of gene expression in the adult mouse brain. Nature 445(7124):168-176. https://doi.org/10.1038/nature05453
Leinninger GM, Jo YH, Leshan RL, Louis GW, Yang H, Barrera JG, Wilson H, Opland DM, Faouzi MA, Gong Y, Jones JC, Rhodes CJ, Chua S Jr, Diano S, Horvath TL, Seeley RJ, Becker JB, Munzberg H, Myers MG Jr (2009) Leptin acts via leptin receptorexpressing lateral hypothalamic neurons to modulate the mesolimbic dopamine system and suppress feeding. Cell Metab 10(2):89-98. https://doi.org/10.1016/j.cmet.2009.06.011

Li P, Schulz S, Bombonati A, Palazzo JP, Hyslop TM, Xu Y, Baran AA, Siracusa LD, Pitari GM, Waldman SA (2007) Guanylyl cyclase C suppresses intestinal tumorigenesis by restricting proliferation and maintaining genomic integrity. Gastroenterology 133(2):599-607. https://doi.org/10.1053/j.gastro.2007.05.052

Li J, Tang Y, Cai D (2012) IKK $\beta / N F-\kappa B$ disrupts adult hypothalamic neural stem cells to mediate a neurodegenerative mechanism of dietary obesity and pre-diabetes. Nat Cell Biol 14(10):999-1012

Li P, Lin JE, Snook AE, Waldman SA (2017) ST-producing E. coli oppose carcinogen-induced colorectal tumorigenesis in mice. Toxins (Basel). https://doi.org/10.3390/toxins9090279

Lieu CA, Subramanian T (2012) The interhemispheric connections of the striatum: implications for Parkinson's disease and druginduced dyskinesias. Brain Res Bull 87(1):1-9. https://doi. org/10.1016/j.brainresbull.2011.09.013

Lin JE, Li P, Snook AE, Schulz S, Dasgupta A, Hyslop TM, Gibbons AV, Marszlowicz G, Pitari GM, Waldman SA (2010) The hormone receptor GUCY2C suppresses intestinal tumor formation by inhibiting AKT signaling. Gastroenterology 138(1):241-254. https://doi.org/10.1053/j.gastro.2009.08.064

Lutter M, Nestler EJ (2009) Homeostatic and hedonic signals interact in the regulation of food intake. J Nutr 139(3):629-632. https:// doi.org/10.3945/jn.108.097618

Magee MS, Abraham TS, Baybutt TR, Flickinger JC Jr, Ridge NA, Marszalowicz GP, Prajapati P, Hersperger AR, Waldman SA, Snook AE (2018) Human GUCY2C-targeted chimeric antigen receptor (CAR)-expressing $\mathrm{T}$ cells eliminate colorectal cancer metastases. Cancer Immunol Res 6(5):509-516. https://doi. org/10.1158/2326-6066.CIR-16-0362

Marszalowicz GP, Snook AE, Magee MS, Merlino D, Berman-Booty LD, Waldman SA (2014) GUCY2C lysosomotropic endocytosis delivers immunotoxin therapy to metastatic colorectal cancer. Oncotarget 5(19):9460-9471. https://doi.org/10.18632/oncot arget. 2455

Mogenson GJ, Jones DL, Yim CY (1980) From motivation to action: functional interface between the limbic system and the motor system. Prog Neurobiol 14(2-3):69-97

Munzberg H, Qualls-Creekmore E, Yu S, Morrison CD, Berthoud HR (2016) Hedonics act in unison with the homeostatic system to unconsciously control body weight. Front Nutr 3:6. https://doi. org/10.3389/fnut.2016.00006

Ng M, Fleming T, Robinson M, Thomson B, Graetz N, Margono C, Mullany EC, Biryukov S, Abbafati C, Abera SF, Abraham JP, Abu-Rmeileh NM, Achoki T, AlBuhairan FS, Alemu ZA, Alfonso R, Ali MK, Ali R, Guzman NA, Ammar W, Anwari P, Banerjee A, Barquera S, Basu S, Bennett DA, Bhutta Z, Blore J, Cabral N, Nonato IC, Chang JC, Chowdhury R, Courville KJ, Criqui MH, Cundiff DK, Dabhadkar KC, Dandona L, Davis A, Dayama A, Dharmaratne SD, Ding EL, Durrani AM, Esteghamati A, Farzadfar F, Fay DF, Feigin VL, Flaxman A, Forouzanfar MH, Goto A, Green MA, Gupta R, Hafezi-Nejad N, Hankey GJ, Harewood HC, Havmoeller R, Hay S, Hernandez L, Husseini A, Idrisov BT, Ikeda N, Islami F, Jahangir E, Jassal SK, Jee SH, Jeffreys M, Jonas JB, Kabagambe EK, Khalifa SE, Kengne AP, Khader YS, Khang YH, Kim D, Kimokoti RW, Kinge JM, Kokubo Y, Kosen S, Kwan G, Lai T, Leinsalu M, Li Y, Liang X, Liu S, Logroscino G, Lotufo PA, Lu Y, Ma J, Mainoo NK, Mensah GA, Merriman TR, Mokdad AH, Moschandreas J, Naghavi M, Naheed A, Nand D, Narayan KM, Nelson EL, Neuhouser ML, Nisar MI, Ohkubo 
T, Oti SO, Pedroza A, Prabhakaran D, Roy N, Sampson U, Seo H, Sepanlou SG, Shibuya K, Shiri R, Shiue I, Singh GM, Singh JA, Skirbekk V, Stapelberg NJ, Sturua L, Sykes BL, Tobias M, Tran BX, Trasande L, Toyoshima H, van de Vijver S, Vasankari TJ, Veerman JL, Velasquez-Melendez G, Vlassov VV, Vollset SE, Vos T, Wang C, Wang X, Weiderpass E, Werdecker A, Wright JL, Yang YC, Yatsuya H, Yoon J, Yoon SJ, Zhao Y, Zhou M, Zhu S, Lopez AD, Murray CJ, Gakidou E (2014) Global, regional, and national prevalence of overweight and obesity in children and adults during 1980-2013: a systematic analysis for the Global Burden of Disease Study 2013. Lancet 384(9945):766-781. https ://doi.org/10.1016/S0140-6736(14)60460-8

Oh SW, Harris JA, Ng L, Winslow B, Cain N, Mihalas S, Wang Q, Lau C, Kuan L, Henry AM, Mortrud MT, Ouellette B, Nguyen TN, Sorensen SA, Slaughterbeck CR, Wakeman W, Li Y, Feng D, Ho A, Nicholas E, Hirokawa KE, Bohn P, Joines KM, Peng H, Hawrylycz MJ, Phillips JW, Hohmann JG, Wohnoutka P, Gerfen CR, Koch C, Bernard A, Dang C, Jones AR, Zeng H (2014) A mesoscale connectome of the mouse brain. Nature 508(7495):207214. https://doi.org/10.1038/nature13186

Patterson CM, Leshan RL, Jones JC, Myers MG Jr (2011) Molecular mapping of mouse brain regions innervated by leptin receptorexpressing cells. Brain Res 1378:18-28. https://doi.org/10.1016/j. brainres.2011.01.010

Perry ML, Leinninger GM, Chen R, Luderman KD, Yang H, Gnegy ME, Myers MG Jr, Kennedy RT (2010) Leptin promotes dopamine transporter and tyrosine hydroxylase activity in the nucleus accumbens of Sprague-Dawley rats. J Neurochem 114(3):666674. https://doi.org/10.1111/j.1471-4159.2010.06757.x

Rodriguez A, Gomez-Ambrosi J, Catalan V, Ezquerro S, MendezGimenez L, Becerril S, Ibanez P, Vila N, Margall MA, Moncada R, Valenti V, Silva C, Salvador J, Fruhbeck G (2016) Guanylin and uroguanylin stimulate lipolysis in human visceral adipocytes. Int J Obes (Lond) 40(9):1405-1415. https://doi.org/10.1038/ ijo.2016.66

Rosenbaum M, Leibel RL (2014) 20 years of leptin: role of leptin in energy homeostasis in humans. J Endocrinol 223(1):T83-T96. https://doi.org/10.1530/JOE-14-0358

Saper CB, Chou TC, Elmquist JK (2002) The need to feed: homeostatic and hedonic control of eating. Neuron 36(2):199-211

Schulz S, Lopez MJ, Kuhn M, Garbers DL (1997) Disruption of the guanylyl cyclase-C gene leads to a paradoxical phenotype of viable but heat-stable enterotoxin-resistant mice. J Clin Investig 100(6):1590-1595. https://doi.org/10.1172/JCI119683

Scott MM, Lachey JL, Sternson SM, Lee CE, Elias CF, Friedman JM, Elmquist JK (2009) Leptin targets in the mouse brain. J Comp Neurol 514(5):518-532. https://doi.org/10.1002/cne.22025

Scott MM, Williams KW, Rossi J, Lee CE, Elmquist JK (2011) Leptin receptor expression in hindbrain Glp-1 neurons regulates food intake and energy balance in mice. J Clin Investig 121(6):24132421. https://doi.org/10.1172/JCI43703

Seeley RJ, Tschop MH (2011) Uroguanylin: how the gut got another satiety hormone. J Clin Investig 121(9):3384-3386. https://doi. org/10.1172/JCI58297

Sisk CL, Nunez AA, Thebert MM (1988) Differential effects of electrolytic and chemical hypothalamic lesions on LH pulses in rats. Am J Physiol 255(5 Pt 1):E583-E590. https://doi.org/10.1152/ ajpendo.1988.255.5.E583

Sohn JW, Elmquist JK, Williams KW (2013) Neuronal circuits that regulate feeding behavior and metabolism. Trends Neurosci 36(9):504-512. https://doi.org/10.1016/j.tins.2013.05.003
Technical white paper: injection sites and steroetaxic coordinates for antegrade projecome (brain-wide) (2016). http://help.brain-map. org/download/attachments/2818171/InjectionSites_and_Stere otaxicCoordinates.pdf. Accessed 29 Mar 2017

Thompson JL, Borgland SL (2013) Presynaptic leptin action suppresses excitatory synaptic transmission onto ventral tegmental area dopamine neurons. Biol Psychiatry 73(9):860-868. https:// doi.org/10.1016/j.biopsych.2012.10.026

Urban MW, Ghosh B, Strojny LR, Block CG, Blazejewski SM, Wright MC, Smith GM, Lepore AC (2018) Cell-type specific expression of constitutively-active Rheb promotes regeneration of bulbospinal respiratory axons following cervical SCI. Exp Neurol 303:108-119. https://doi.org/10.1016/j.expneurol.2018.02.007

Valentino MA, Lin JE, Snook AE, Li P, Kim GW, Marszalowicz G, Magee MS, Hyslop T, Schulz S, Waldman SA (2011) A uroguanylin-GUCY2C endocrine axis regulates feeding in mice. J Clin Investig 121(9):3578-3588. https://doi.org/10.1172/JCI57925

Waldman SA, Camilleri M (2018) Guanylate cyclase-C as a therapeutic target in gastrointestinal disorders. Gut. https://doi.org/10.1136/ gutjnl-2018-316029

Wang HG, Lu FM, Jin I, Udo H, Kandel ER, de Vente J, Walter U, Lohmann SM, Hawkins RD, Antonova I (2005) Presynaptic and postsynaptic roles of NO, cGK, and RhoA in long-lasting potentiation and aggregation of synaptic proteins. Neuron 45(3):389403. https://doi.org/10.1016/j.neuron.2005.01.011

Wang YC, McPherson K, Marsh T, Gortmaker SL, Brown M (2011) Health and economic burden of the projected obesity trends in the USA and the UK. Lancet 378(9793):815-825. https://doi. org/10.1016/S0140-6736(11)60814-3

Waterson MJ, Horvath TL (2015) Neuronal regulation of energy homeostasis: beyond the hypothalamus and feeding. Cell Metab 22(6):962-970. https://doi.org/10.1016/j.cmet.2015.09.026

Watts AG (2000) Understanding the neural control of ingestive behaviors: helping to separate cause from effect with dehydrationassociated anorexia. Horm Behav 37(4):261-283. https://doi. org/10.1006/hbeh.2000.1581

Weinberg DS, Lin JE, Foster NR, Della'Zanna G, Umar A, Seisler D, Kraft WK, Kastenberg DM, Katz LC, Limburg PJ, Waldman SA (2017) Bioactivity of oral linaclotide in human colorectum for cancer chemoprevention. Cancer Prev Res (Phila) 10(6):345-354. https://doi.org/10.1158/1940-6207.CAPR-16-0286

Williams KW, Liu T, Kong X, Fukuda M, Deng Y, Berglund ED, Deng Z, Gao Y, Liu T, Sohn JW, Jia L, Fujikawa T, Kohno D, Scott MM, Lee S, Lee CE, Sun K, Chang Y, Scherer PE, Elmquist JK (2014) Xbp1s in Pomc neurons connects ER stress with energy balance and glucose homeostasis. Cell Metab 20(3):471-482. https://doi.org/10.1016/j.cmet.2014.06.002

You YJ, Kim J, Raizen DM, Avery L (2008) Insulin, cGMP, and TGF-beta signals regulate food intake and quiescence in C. elegans: a model for satiety. Cell Metab 7(3):249-257. https://doi. org/10.1016/j.cmet.2008.01.005

Zigman JM, Bouret SG, Andrews ZB (2016) Obesity impairs the action of the neuroendocrine ghrelin system. Trends Endocrinol Metab 27(1):54-63. https://doi.org/10.1016/j.tem.2015.09.010

Zufall F, Shepherd GM, Barnstable CJ (1997) Cyclic nucleotide gated channels as regulators of CNS development and plasticity. Curr Opin Neurobiol 7(3):404-412

Publisher's Note Springer Nature remains neutral with regard to jurisdictional claims in published maps and institutional affiliations. 